\title{
The volume-regulated anion channel (LRRC8) in nodose neurons is sensitive to acidic $\mathrm{pH}$
}

\author{
Runping Wang, ${ }^{1,2}$ Yongjun Lu, ${ }^{1,2}$ Susheel Gunasekar, ${ }^{1,2}$ Yanhui Zhang, ${ }^{1,2}$ Christopher J. Benson, ${ }^{1,2,3}$ \\ Mark W. Chapleau, ${ }^{1,2,3,4}$ Rajan Sah, ${ }^{1,2,4}$ and François M. Abboud ${ }^{1,2,4}$ \\ 'Department of Internal Medicine, ${ }^{2}$ Abboud Cardiovascular Research Center, University of lowa, lowa City, lowa, USA. \\ ${ }^{3}$ Veterans Affairs Medical Center, lowa City, lowa, USA. ${ }^{4}$ Department of Molecular Physiology and Biophysics, University of \\ lowa, lowa City, lowa, USA
}

The leucine rich repeat containing protein 8A (LRRC8A), or SWELL1, is an essential component of the volume-regulated anion channel (VRAC) that is activated by cell swelling and ionic strength. We report here for the first time to our knowledge its expression in a primary cell culture of nodose ganglia neurons and its localization in the soma, neurites, and neuronal membrane. We show that this neuronal VRAC/SWELL1 senses low external $\mathrm{pH}\left(\mathrm{pH}_{0}\right)$ in addition to hypoosmolarity. A robust sustained chloride current is seen in $77 \%$ of isolated nodose neurons following brief exposures to extracellular acid pH. Its activation involves proton efflux, intracellular alkalinity, and an increase in NOX-derived $\mathrm{H}_{2} \mathrm{O}_{2}$. The molecular identity of both the hypoosmolarity-induced and acid $\mathrm{pH}_{\mathrm{o}}$-conditioned VRAC as LRRC8A (SWELL1) was confirmed by Cre-flox-mediated KO, shRNAmediated knockdown, and CRISPR/Cas9-mediated LRRC8A deletion in HEK cells and in primary nodose neuronal cultures. Activation of VRAC by low $\mathrm{pH}_{0}$ reduces neuronal injury during simulated ischemia and $\mathrm{N}$-methyl-D-aspartate-induced (NMDA-induced) apoptosis. These results identify the VRAC (LRRC8A) as a dual sensor of hypoosmolarity and low $\mathrm{pH}_{\mathrm{o}}$ in vagal afferent neurons and define the mechanisms of its activation and its neuroprotective potential.

Conflict of interest: The authors have declared that no conflict of interest exists.

Submitted: September 9, 2016 Accepted: January 26, 2017 Published: March 9, 2017

Reference information: JCI Insight. 2017;2(5):e90632. https:// doi.org/10.1172/jci.insight.90632.

\section{Introduction}

The majority of neurosensory signals that trigger autonomic responses are mediated by sensory afferents of the nodose ganglia (NG) and dorsal root ganglia (DRG). It is generally recognized that activation of vagal sensory afferents of nodose neurons that innervate most visceral organs either mechanically or chemically evokes sympatho-inhibitory and parasympathetic reflexes (1-7). Conversely, excitation of the DRG spinal afferents induces excitatory sympathetic reflexes (8). Responses of DRG neurons to various mediators of nociception and particularly to acidic $\mathrm{pH}$ have been extensively reported $(9,10)$. On the other hand, studies of $\mathrm{pH}$ sensitivity of nodose ganglion neurons have been more limited $(11,12)$, and when contrasted with DRG neurons, the nodose neurons were markedly less $\mathrm{pH}$ sensitive $(13,14)$.

In earlier work on acid sensing ion channels (ASICs), we found that ASIC2, the least $\mathrm{pH}$ sensitive ASIC subunit, is relatively much more expressed in aortic baroreceptor neurons of the NG and is essential for their mechanosensitivity (15), whereas the acid sensitive subunits ASIC1 and ASIC3 were relatively highly expressed in the $\mathrm{pH}$-sensitive glomus cells of the carotid chemoreceptors but poorly expressed in the NG However, the wide network of vagal afferents of nodose neurons in several organs is exposed to significant reductions in tissue $\mathrm{pH}$ in pathological states and in ischemic conditions $(9,16,17)$. Therefore, our initial goal in this study was to characterize the proton-sensitive currents of nodose sensory neurons. The most prevalent current was a large and prolonged inward current that was activated following brief exposures to low $\mathrm{pH}_{\mathrm{o}}$ This $\mathrm{pH}_{\mathrm{o}}$-conditioned current was similar to the swelling-activated $\mathrm{Cl}$ current (SAC) induced by hypoosmolarity. We defined its identity as the volume-regulated anion channel (VRAC), for which the leucine-rich repeat containing protein $8 \mathrm{~A}$ (LRRC8A), or SWELL1, was reported to be an essential component $(18,19)$ and more recently reported as a sensor of ionic strength gradients in the absence of osmotic gradient (20). We confirmed for the first time to our knowledge in a primary culture the molecular identity of LRRC8A in the soma and neurites of nodose neurons. We further described the mechanisms of its activation and its neuroprotective effect during simulated ischemia and glutamate-induced apoptosis. 


\section{Results}

Using whole-cell patch-clamp on isolated nodose ganglion neurons, we first identified transient and sustained cationic currents in response to low $\mathrm{pH}_{\mathrm{o}}$, which were similar to those reported in DRG neurons (21, 22). These are described in the Supplemental Material (Supplemental Figure 1 and 2; supplemental material available online with this article; https://doi.org/10.1172/jci.insight.90632DS1).

\section{Novel anionic current induced by low $\mathrm{pH}_{0}$ in nodose ganglion neurons}

Our unexpected observation was a large inward current that followed 1-3 brief exposures to $\mathrm{pH}_{\mathrm{o}} 6.0$ and occurred in a large majority (77\%) of the neurons (Figure 1A). The kinetics of activation and inactivation were extremely slow, with a duration of 10-15 minutes at room temperature. We therefore refer to this current as prolonged $\mathrm{pH}_{\mathrm{o}}$-conditioned current. The rest of our studies focused on this unique acid-evoked current.

To standardize its activation, neurons were sequentially exposed to low $\mathrm{pH}_{\mathrm{o}} 3$ times for 10 seconds each, with a 20 -second interval between exposures at normal $\mathrm{pH}_{\mathrm{o}} 7.4$ (Figure $1 \mathrm{~A}$ ). After the 3 pulses of $\mathrm{pH}_{\mathrm{o}}$ 6.0 and the return to $\mathrm{pH}_{\mathrm{o}} 7.4$, the conditioned current was relatively large $(904.3 \pm 159.9 \mathrm{pA}, n=17)$ with a density of $21.2 \pm 2.7 \mathrm{pA} / \mathrm{pF}$. Smaller currents were also induced by more modest reductions in $\mathrm{pH}_{\mathrm{o}}$ to 6.5 and 7.0 (Figure 1A).

\section{The prolonged $\mathrm{pH}_{0}$-conditioned inward current is the result of outward $\mathrm{Cl}^{-}$conductance}

To define the ionic nature of this current, we first replaced extracellular $\mathrm{Na}^{+}$and $\mathrm{Ca}^{2+}$ with $\mathrm{N}$-methyld-glucamine (NMDG) and found no significant reduction in the $\mathrm{pH}_{\mathrm{o}}$-conditioned current (Figure $1 \mathrm{~B}$ ). Replacement of intracellular $\mathrm{K}^{+}$with $\mathrm{Cs}^{+}$also had no effect on the current (Figure 1B). In fact, when all permeable cations were removed and replaced with extracellular NMDG and intracellular $\mathrm{Cs}^{+}$, the current was maintained. By contrast, reducing intracellular $\mathrm{Cl}^{-}$to $4 \mathrm{mM}$ substituting aspartate abolished the current $(0.6 \pm 0.2 \mathrm{pA} / \mathrm{pF}$, Figure $1 \mathrm{~B})$, suggesting that the prolonged $\mathrm{pH}_{\mathrm{o}}$-conditioned current is the result of an outward $\mathrm{Cl}^{-}$conductance.

Membrane depolarization. Under current clamp conditions and equimolar concentrations of intra- and extracellular $\mathrm{Cl}^{-}(133 \mathrm{mM})$ making the equilibrium potential $0 \mathrm{mV}$, the 3 pulses of $\mathrm{pH}_{\mathrm{o}} 6.0$ were followed by a large and sustained depolarization that frequently triggered action potentials (Figure $1 \mathrm{C}$ ). To test the contribution of this $\mathrm{pH}_{\mathrm{o}}$-conditioned $\mathrm{Cl}^{-}$conductance to the membrane potential at a physiologic intracellular $\mathrm{Cl}^{-}$concentration, we used gramicidin, a polypeptide antibiotic that forms monovalent cation channels on the cell membrane that are impermeable to anions (23). Under current clamp conditions and using gramicidin to form a perforated patch, the equilibrium potential was more negative and the extracellular $\mathrm{pH}_{\mathrm{o}} 6.0$ exposures caused substantial but, as expected, lesser sustained depolarization averaging $12.7 \pm 3.4 \mathrm{mV}$ (Figure 1C).

Current-voltage relationship. We next tested the reversal potential during the peak activation of the current following 3 brief exposures to $\mathrm{pH}_{\mathrm{o}} 6.0$ (Figure 2A). The peak current was stable for approximately 1-2 minutes; allowing sufficient time $(<20 \mathrm{sec}$ ) to obtain I-V curves (Figure $2 \mathrm{~A}$ ). To eliminate the confounding contribution of voltage-gated cationic currents, we used NMDG to replace all permeable cations. Under such conditions with equimolar intra- and extracellular concentrations of $\mathrm{Cl}^{-}(133 \mathrm{mM})$, the reversal potential was very near $0 \mathrm{mV}$ with a small degree of outward rectification (Figure $2 \mathrm{~A}$ ). Reducing extracellular $\left[\mathrm{Cl}^{-}\right]$ from 133-68 $\mathrm{mM}$ and then to $4 \mathrm{mM}$ shifted the reversal potential progressively to a more positive voltage in a logarithmically linear fashion. Conversely a reduction in intracellular $\mathrm{Cl}^{-}$to $4 \mathrm{mM}$ shifted the reversal potential to a negative value and essentially eliminated the inward current (Figure 2A).

Collectively, these data demonstrate that the prolonged $\mathrm{pH}_{\mathrm{o}}$-conditioned current is the result of an outward $\mathrm{Cl}^{-}$conductance that causes a significant depolarization even at physiologic intracellular $\mathrm{Cl}^{-}$concentrations reported to be $\sim 40-60 \mathrm{mM}$ in peripheral neurons $(24,25)$. Since $\mathrm{Ca}^{2+}$-dependent $\mathrm{Cl}^{-}$ channels $(\mathrm{CaCC})$ have been reported in nodose ganglion neurons to be activated by bradykinin (3), we tested the effect of the CaCC blocker niflumic acid $(100 \mu \mathrm{M})$, and it did not inhibit the $\mathrm{pH}_{\mathrm{o}}$-conditioned current (Figure 2B).

The prolonged $\mathrm{pH}_{0}$-conditioned current resembles a SAC

We next wondered whether the $\mathrm{pH}_{\mathrm{o}}$-conditioned current is carried by the SAC channel known to be activated by hypoosmolarity $(26,27)$. We found that nodose ganglion neurons did respond to a hypoosmotic extracellular stimulus $(210 \mathrm{mOsm})$ with a large and prolonged current that was reproducible with 
A Prolonged $\mathrm{pH}$-conditioned current
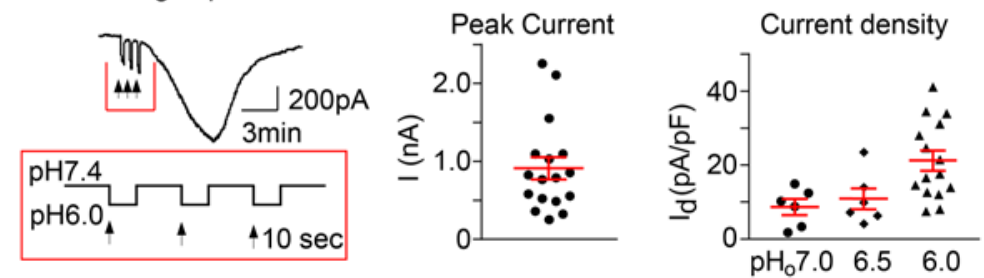

B $\mathrm{Cl}^{-}$selectivity of the current
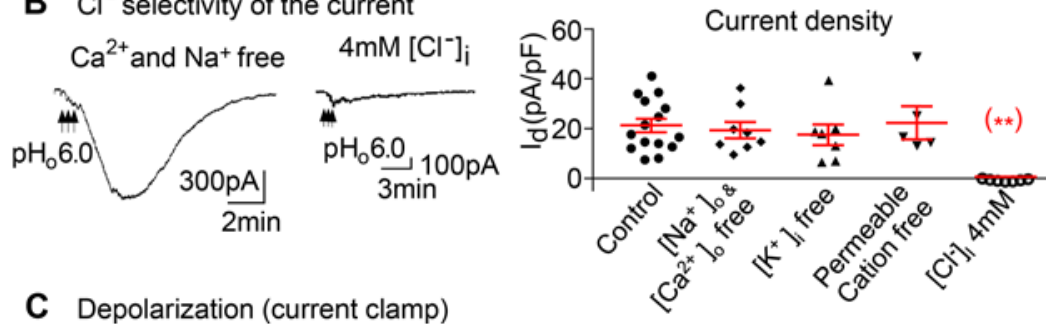

C Depolarization (current clamp) At equimolar $\left[\mathrm{Cl}^{-}\right]_{j} \&\left[\mathrm{Cl}^{-}\right]_{0}$
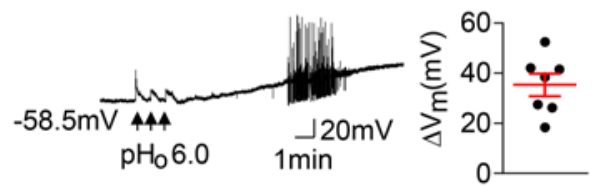

At physiologic $\left[\mathrm{Cl}^{-}\right]_{i}$ (gramicidin)

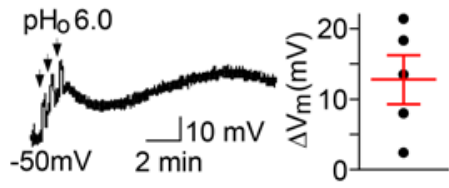

Figure 1. A prolonged $\mathrm{pH}_{0}$-conditioned inward current and depolarizations. (A) A representative inward current evoked from a nodose neuron after 3 brief sequential exposures to extracellular $\mathrm{pH}_{0} 6.0$, indicated by the vertical black arrows. The membrane potential was held at $-60 \mathrm{mV}$. The peak currents seen in 17 of 22 individual neurons are shown. The current density is $\mathrm{pH}_{0}$ dependent and averaged $8.5 \pm 2.1 \mathrm{pA} / \mathrm{pF}$ for $\mathrm{pH}_{0} 7.0$ ( $n=2$ mice); $10.8 \pm 2.9 \mathrm{pA} /$ $\mathrm{pF}$ for $\mathrm{pH}_{0} 6.5$ ( $n=2$ mice); $21.2 \pm 2.7 \mathrm{pA} / \mathrm{pF}$ for $\mathrm{pH}_{0} 6.0$ ( $n=6$ mice, $P=0.037$ by ANOVA). (B) The currents evoked in control solutions (21.2 $\pm 2.7 \mathrm{pA} / \mathrm{pF}, n=3$ mice) are maintained in extracellular $\mathrm{Ca}^{2+}$ and $\mathrm{Na}^{+}$free solution ( $19.3 \pm 3.1 \mathrm{pA} / \mathrm{pF}, n=3$ mice), in intracellular $\mathrm{K}^{+}$free solutions (17.4 $\pm 4.2 \mathrm{pA} / \mathrm{pF}, n=5$ mice ), and in solutions free of all permeable cations ( $25.9 \pm$ $6.6 \mathrm{pA} / \mathrm{pF}, n=3$ mice $)$ but are absent in solutions of $4 \mathrm{mM}$ intracellular $\mathrm{Cl}^{-}(0.6 \pm 0.2 \mathrm{pA} / \mathrm{pF}$, $n=5$ mice, ${ }^{* *} P<0.001$ vs. control by ANOVA). (C) Under current clamp conditions, progressive depolarizations and action potentials were evoked following the transient sequential $\mathrm{pH}_{0} 6.0$ applications (black arrows). The tracing and panel to the left show the mean maximum depolarizations of $35.2 \pm 4.4 \mathrm{mV}\left(n=5\right.$ mice) at equimolar $(133 \mathrm{mM})\left[\mathrm{Cl}^{-}\right]_{i}$ and $\left[\mathrm{Cl}^{-}\right]_{0}$ and an equilibrium potential of $\sim 0 \mathrm{mV}$. The tracing and panel to the right show the membrane potential and maximum depolarizations recorded with the perforated patch clamp using gramicidin to maintain physiologic intracellular $\left[\mathrm{Cl}^{-}\right]_{i}$ and an equilibrium potential that is more negative hence a lesser maximal depolarization ( $12.7 \pm 3.4 \mathrm{mV}, n=2$ mice). All panels include responses of individual neurons and the means $\pm \mathrm{SE}$. a second exposure to $210 \mathrm{mOsm}$ and with kinetics that were very similar to the $\mathrm{pH}_{\mathrm{o}}$-conditioned current (Figure 2C). The neurons fully recovered their responses to hypoosmolarity.

Comparable I-V curve. The similarity between the 2 currents was also evident when their I-V curves were compared. When the neurons were maintained in a solution free of permeable cations, the I-V curves during the peak response to hypoosmolarity had a reversal potential close to 0 at equimolar intra- and extracellular $\left[\mathrm{Cl}^{-}\right]$(Figure 2C). Lowering the extracellular $\mathrm{Cl}^{-}$concentration shifted the reversal potential to more positive voltages, as seen with the low $\mathrm{pH}_{\mathrm{o}}$-conditioned current (Figure 2, A and C).

Convergence of stimuli. Finally, we tested the response of nodose neurons to the combined stimulation with low $\mathrm{pH}_{\mathrm{o}}$ and hypoosmolarity. As shown in Supplemental Figure 3, A and B, the response to the added stimuli together was not significantly larger than the response to either stimulus alone, suggesting a possible convergence of the mechanical and the chemical stimuli on the same pathway leading to activation of SAC.

\section{LRRC8A (SWELL1), a component of the} VRAC, is expressed in nodose neurons and is essential for induction of the $\mathrm{Cl}^{-}$current by hypoosmolarity and low $\mathrm{pH}_{0}$

The gene product LRRC8 (SWELL1) is an essential component of the SAC channel, which is also identified as VRAC. The major subunit LRRC8A forms a heteromeric hexamer that may include one or more subunits (B-E), and its deletion greatly reduces the hypoosmolarity-induced current (18, 19). Here, we show that DCPIB $(30 \mu \mathrm{M})$, a specific blocker of VRAC (LRRC8), inhibits promptly both the $\mathrm{pH}_{\mathrm{o}}$-conditioned and hypoosmolarity-induced currents and reduces their current densities significantly (Figure 3A). The currents are quickly restored after removal of DCPIB (Figure 3A).

LRRC8A mRNA and protein are expressed in several neuronal tissues including brain stem ganglia, NG, and DRG ganglia, as well as in HEK293 cells and other tissues - namely heart, aorta, and small intestine (Figure 3B). The HEK293 cell line with CRISPR/Cas9-mediated LRRC8A deletion did not show any protein expression (Figure 3B).

We used lentivirus carrying 2 shRNAs to target different LRRC8A sequences in nodose neurons in culture. The targeted sequences by both shRNA1 and shRNA2 were located the conserved region of LRRC8A that showed 100\% homology of human and mouse sequences (Figure 3C). We also used nodose neurons from mice containing the floxed allele of LRRC8A and transduced them with lentivirus carrying Cre-recombinase to knock out the LRRC8A protein in culture. In the nodose neurons transduced with either Cre (for neurons from floxed mice) or shRNA1 or -2 (for neurons from WT mice), we found that both the $\mathrm{pH}_{\mathrm{o}}$-conditioned and hypoosmolarity-induced currents were significantly reduced compared with the corresponding control neurons transduced with GFP or empty vector, respectively (Figure 3D). Evidently, LRRC8A is equally essential for mediating the $\mathrm{pH}_{\mathrm{o}}$-conditioned current as the hyposmolarity-induced current. 
A I-V relationship of $\mathrm{pH}_{\mathrm{o}}$-conditioned $\mathrm{Cl}^{-}$current

(Permeable cation free solution)
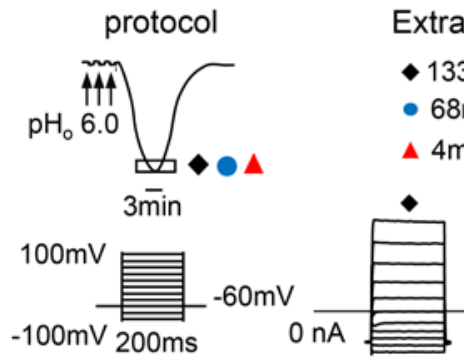

$[\mathrm{Cl}]_{0} \& \mathrm{E}_{\text {rev }}$ relationship

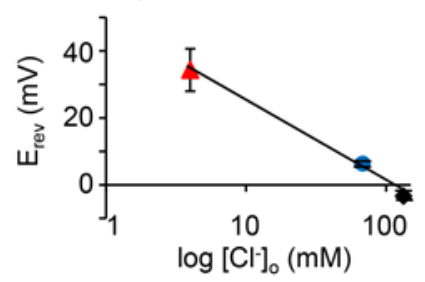

B $\mathrm{pH}_{\mathrm{o}}$ conditioned $\mathrm{Cl}^{-}$currents
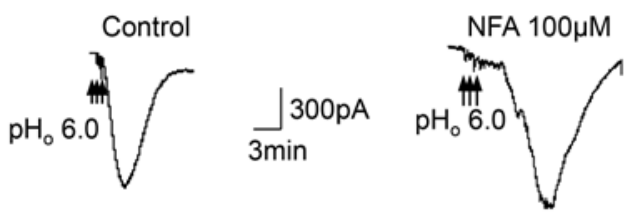

\section{Hypoosmolarity induced currents}
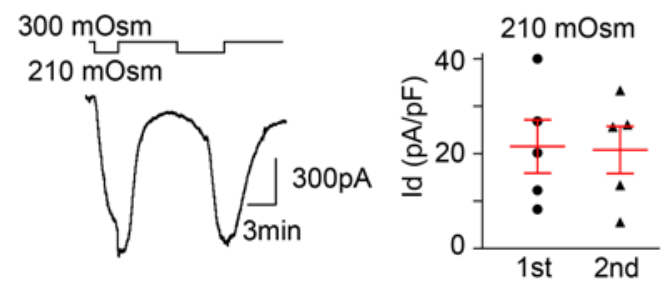

I-V relationship $(210 \mathrm{mOsm})$ $133 \mathrm{mM}[\mathrm{Cl}]_{i}$

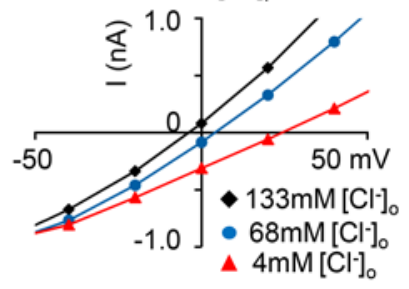

Figure 2. The prolonged $\mathrm{pH}_{0}$-conditioned current is $\mathrm{Cl}^{-}$selective and similar to the hypoosmolarity-induced current. (A) The current-voltage (I-V) relationship was obtained during the peak activation of the $\mathrm{pH}_{0}$-conditioned current (boxed area at the nadir of the curve). The voltage was changed from $-100 \mathrm{mV}$ to $+100 \mathrm{mV}$ with $20 \mathrm{mV}$ increments, each lasting $200 \mathrm{~ms}$ with an interval of 1 second. The holding potential was $-60 \mathrm{mV}$. Overlay of currents recorded during the I-V protocol described above were obtained in solutions free of intra- and extracellular cations under 3 different conditions: one with equivalent intra- and extracellular [ $\left.\mathrm{Cl}^{-}\right]$of $133 \mathrm{mM}$ and the other 2 with intracellular [ $\left.\mathrm{Cl}^{-}\right]_{i}$ of 133 $\mathrm{mM}$ and extracellular $\left[\mathrm{Cl}^{-}\right]_{0}$ of 68 and $4 \mathrm{mM}$. The I-V curve obtained with equivalent concentrations of [Cl-] (black) has a reversal potential of $-3.32 \pm 0.63 \mathrm{mV}$; the reversal potential for 68 (blue) and 4 $\mathrm{mM}$ of $\left[\mathrm{Cl}^{-}\right]_{0}$ (red) are $6.34 \pm 0.55 \mathrm{mV}$ and $34.33 \pm 2.57 \mathrm{mV}$. The curve relating the reversal potential to the log of $\left[\mathrm{Cl}^{-}\right]_{0}$ concentration displays a linear relationship ( $n=5$ neurons from 3 mice). The I-V curve recorded at $4 \mathrm{mM}$ intracellular [ $\left.\mathrm{Cl}^{-}\right]$, and normal $133 \mathrm{mM}$ extracellular [ $\left.\mathrm{Cl}^{-}\right]$(green) shows a shift in the reversal potential to a negative voltage ( $-26.4 \pm 3.8 \mathrm{mV}, n=3$ neurons from 1 mouse). Notice that the inward current is nearly eliminated. (B) The tracings show $\mathrm{pH}_{0}$-conditioned currents unaltered in the presence of $100 \mu \mathrm{M}$ niflumic acid (NFA), the $\mathrm{Ca}^{2+}$-activated $\mathrm{Cl}^{-}$channel blocker. The panel shows mean $\mathrm{pH}_{0} 6.0$ conditioned current densities in control neurons ( $22.5 \pm 4.7 \mathrm{pA} / \mathrm{pF} ; n=3$ mice) vs. NFA-treated neurons (17.9 $\pm 5.0 \mathrm{pA} / \mathrm{pF} ; n=3$ mice; $P>0.05$; unpaired 2-tailed student's $t$ test). (C) Tracings show that typical large inward currents evoked in nodose neurons by 2 consecutive exposures to hypoosmolarity $(210 \mathrm{mOsm})$ are reproducible, and the kinetics resemble the low $\mathrm{pH}_{0}$ conditioned current. The panel shows that the mean current densities \pm SE are $21.5 \pm 5.6$ for the first and $20.8 \pm 5.0 \mathrm{pA} / \mathrm{pF}$ for the second exposure ( $n=4$ mice, $P>0.05$; paired 2-tailed Student's $t$ test). They are also similar to the $\mathrm{pH}_{0}$-conditioned currents shown above in $\mathbf{B}$. The I-V relationship obtained near the nadir of the current induced by $210 \mathrm{mOsm}$ is also similar to that induced by low $\mathrm{pH}_{0}$ and shows a reversal potential near 0 at equimolar $\left[\mathrm{Cl}^{-}\right]_{\mathrm{i}}\left(-4.2 \mathrm{mV}\right.$ ) with $\left[\mathrm{Cl}^{-}\right]_{0}$ of $133 \mathrm{mM}$ (black) and a progressive shift to more positive potentials with reduced $\left[\mathrm{Cl}^{-}\right]_{0}$ to $68(3.6 \mathrm{mV})$ and $4 \mathrm{mM}(24.5 \mathrm{mV})$ (blue and red, respectively).
We compared currents induced by hypoosmolarity and $\mathrm{pH}_{\mathrm{o}}$ conditioning in $\mathrm{NG}$ and $\mathrm{DRG}$ neurons and HEK293 cells and found that all 3 cell types respond to hypoosmolarity, whereas the $\mathrm{pH}_{0}$-conditioned response is seen predominantly in nodose neurons and minimally in DRG and HEK293 cells (Figure 3E). The activation mechanisms of VRAC/LRRC8 in its native cellular environment are clearly more complex and may differ in different cells.

LRRC8A expression in nodose neurons. The mRNA and protein measurements using quantitative PCR (qPCR) and Western blots were made on a sufficiently large number of neurons isolated from NG of 5 mice for each measurement. The neuronal cultures were treated with lentivirus containing empty vector, shRNA2, or Cre and maintained for 6 days prior to analysis.

The shRNA2-mediated knockdown and Cre-flox-mediated KO of LRRC8A in nodose neurons resulted in an $88 \%$ and $78 \%$ decrease in mRNA levels, respectively. Protein measurements showed a $67 \%$ reduction in neuronal cultures transduced with shRNA2 (Figure 4A).

Using immunostaining with LRRC8A antibody, we found native LRRC8A protein (red) expressed in nodose neurons including their dendritic projections and is colocalized with the blue neuronal marker NeuN (Figure 4B). The expression is not evident in nonneuronal cells, but it is obvious on the membrane of the magnified neuronal images (Figure 4B), as well as on the membrane of HEK293 cells as shown in the Supplement (Supplemental Figure 4). The LRRC8A immunofluorescence was substantially reduced in shRNA2-transduced neurons (Figure 4C), as well as in the Cre-transduced LRRC8A floxed neurons (Figure $4 \mathrm{D}$ ). The quantitation of immunofluorescence when normalized to control neurons transduced with GFP or control empty vector showed statistically significant reductions of $\sim 50 \%$ in a large number of Cre- as well as shRNA2-transduced neurons (Figure 4E).

NADPH oxidase-derived (NOX-derived) $\mathrm{H}_{2} \mathrm{O}_{2}$ is required for $\mathrm{pH}_{0}$-conditioned and hypoosmolarity-induced activation of LRRC8 current

Since ROS are implicated in the activation of VRAC in response to stretch or swelling of the plasma membrane $(28,29)$, we asked whether $\mathrm{ROS}$ also mediate the $\mathrm{pH}_{\mathrm{o}}$-conditioned current. 
A Inhibition of currents by $30 \mu \mathrm{M} \mathrm{DCPIB}$
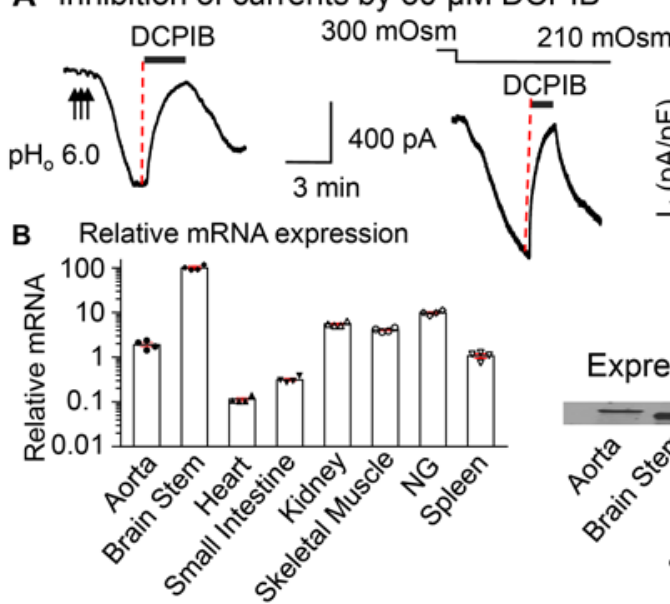

C Sequence of shRNA1 (red) and 2 (green)

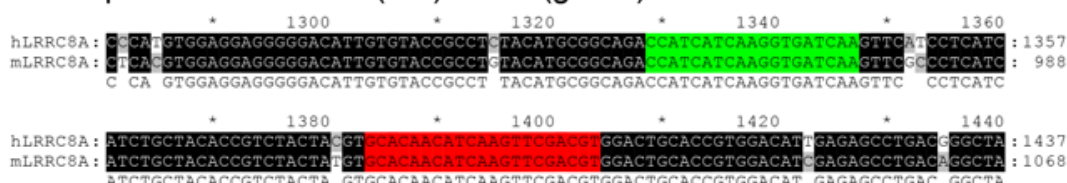

\section{Reduction of current by LRRC8A knockdown}
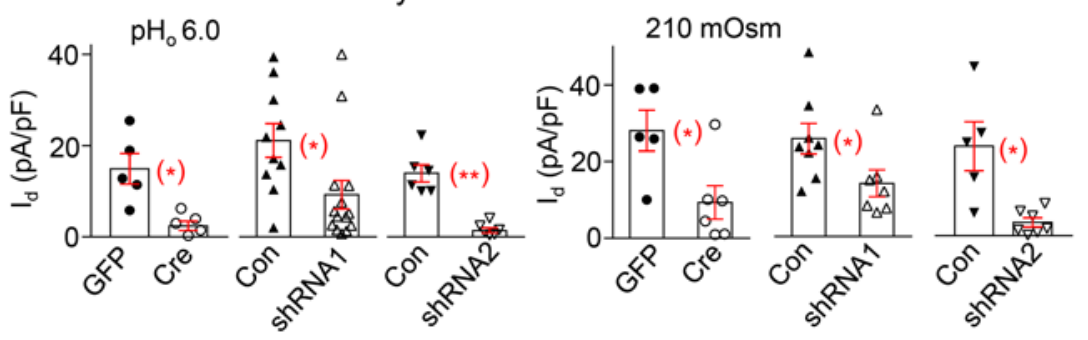

E Contrasting current responses
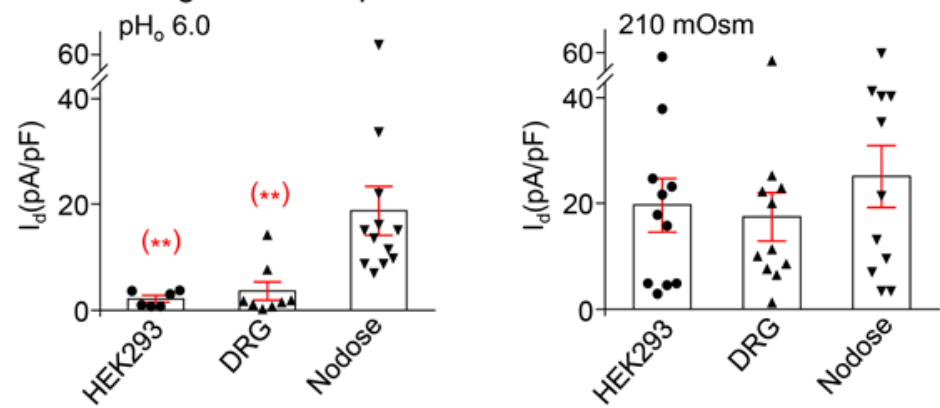

Figure 3. Leucine-rich repeat containing protein $8 \mathrm{~A}$ (LRRC8A) in nodose neurons is essential for activation of low $\mathrm{pH}_{0}$-conditioned and hypoosmolarityinduced $\mathrm{Cl}^{-}$currents. (A) The tracings and panels show that the $\mathrm{pH}$-conditioned current densities $\left(\mathrm{I}_{\mathrm{d}}\right)$ induced by $\mathrm{pH}_{0} 6.0$ is inhibited from $29.5 \pm 4.3 \mathrm{pA} / \mathrm{pF}$ to $3.5 \pm$ $0.2 \mathrm{pA} / \mathrm{pF}$ after application of $30 \mu \mathrm{M}$ DCPIB, the blocker of VRAC/LRRC8 ( $n=2$ mice, $\left.{ }^{*} P<0.05\right)$. Similarly, the hypoosmolarity-induced current is inhibited from $37.4 \pm 4.7 \mathrm{pA} / \mathrm{pF}$ to $5.6 \pm 2.1 \mathrm{pA} / \mathrm{pF}$ by $30 \mu \mathrm{M} \mathrm{DCPIB}(n=$ 4 mice, $\left.{ }^{* *} P<0.001\right)$. Both currents quickly recover following the wash out of DCPIB. (B) RT PCR and Western blots show relative mRNA (normalized to the expression level in spleen) and protein expression of LRRC8A in a variety of tissues ( $n=4$ mice) and the absence of LRRC8 protein in HEK293 KO cells. (c) The sequences targeted by shRNA-1 (red) and shRNA2 (green) against LRRC8A. The sequences of human $(h)$ and mouse (m) LRRC8A listed show $100 \%$ homology. (D) Cre recombinase-mediated LRRC8A excision in nodose neurons from floxed mice reduces the $\mathrm{pH}_{0}$-conditioned VRAC current density $\left(I_{d} \mathrm{pA} / \mathrm{pF}\right.$ ) from14.9 \pm 3.4 (GFP transduced, $n=4$ mice) to $2.4 \pm 1.0$ (Cre transduced, $n$ $=6$ mice, $\left.{ }^{*} P<0.05\right)$ and the hypoosmolarity current from $28.1 \pm 5.4$ (GFP transduced, $n=2$ mice) to $9.3 \pm$ $4.4 \mathrm{pA} / \mathrm{pF}$ (Cre transduced, $n=3$ mice, $\left.{ }^{*} P<0.05\right)$. LRRC8A knock down (KD) in shRNA1-transduced neurons reduces responses to the $\mathrm{pH}_{0}$-conditioned currents from $21.2 \pm 3.7$ in WT control mice (Con, $n=7$ ) to $9.2 \pm$ 3.1 (KD, $n=7$ mice; ${ }^{*} P<0.05$ ), and those to hypoosmolarity from $25.6 \pm 4.0$ (Con, $n=5$ ) to $13.9 \pm 3.5(K D$, $n=3$ mice; $\left.{ }^{*} P<0.05\right)$. Corresponding values in control vs. shRNA2 transduced neurons are $14.0 \pm 1.9$ (Con, $n=3$ ) vs. $1.4 \pm 0.6$ (KD, $n=3$ mice; ${ }^{*} P<0.001$ ) with $\mathrm{pH}_{0}$-conditioned current; and $23.4 \pm 6.4$ (Con, $n=3$ ) vs. $3.5 \pm 1.2$ (KD, $n=3$ mice; ${ }^{*} P<0.05$ ) with hypoosmolarity. (E) The $\mathrm{pH}_{0}$-conditioned and hypoosmolarity-induced VRAC current densities are compared in nodose neurons vs. DRG neurons and HEK 293 cells. Although all 3 groups respond to hypoosmolarity ( $19.7 \pm 5.1$ for HEK 293, $n=2 ; 17.5 \pm 4.6$ for DRG, $n=5$ mice; and $25.1 \pm$ $5.8 \mathrm{pA} / \mathrm{pF}$ for nodose, $n=5$ mice), the $\mathrm{pH}_{0}$-conditioned current is seen predominantly in nodose neurons (18.8 $\pm 4.6, n=5$ mice) and minimally $\left.{ }^{* *} P<0.01\right)$ in DRG ( $3.6 \pm 1.7, n=5$ mice) and HEK293 cells ( $2.1 \pm 0.6 \mathrm{pA} / \mathrm{pF}$, $n=2$ mice). All symbols within bars indicate individual neurons. Statistical comparisons of all means \pm SE unpaired 2-tailed Student's $t$ test.

ROS generation as determined by dihydroethidine (DHE) fluorescence increases sharply in nodose ganglion neurons following the brief exposures to low $\mathrm{pH}_{\mathrm{o}} 6.0$ solutions (Figure $5, \mathrm{~A}-\mathrm{D}$ ). The rapid rate of ROS accumulation seen in Figure 5D is temporally related to the peak activation of the $\mathrm{pH}$-conditioned current seen within minutes following the low $\mathrm{pH}_{\mathrm{o}}$ exposures as shown in Figures 1-3.

The superoxide scavenger superoxide dismutase (PEG-SOD) does not reduce the $\mathrm{pH}_{\mathrm{o}}$-conditioned current (Figure 6A). On the other hand, $\mathrm{H}_{2} \mathrm{O}_{2}$ depletion with PEG-catalase attenuates the $\mathrm{pH}_{\mathrm{o}}$-conditioned current (Figure 6B).

The current is also strongly attenuated by NOX inhibitors apocynin and diphenyleneiodonium (DPI) (Figure 6C), indicating that NOX activation is required for induction of the current. The hypoosmolarity-induced current is abrogated by PEG-catalase, as is the $\mathrm{pH}_{\mathrm{o}}$-conditioned one (Figure 6D). We also find that exposure of nodose ganglion neurons to $1 \mathrm{mM} \mathrm{H}_{2} \mathrm{O}_{2}$ induces a current with similar kinetics as the $\mathrm{pH}_{\mathrm{o}}$-conditioned and the hypoosmolarity-induced currents (Figure 6E). Collectively, the results suggest that $\mathrm{H}_{2} \mathrm{O}_{2}$ mediates channel activation induced by both hypoosmolarity and low $\mathrm{pH}_{\mathrm{o}}$. 
A shRNA2 and flox-Cre reduce LRRC8A mRNA \& protein expression Relative mRNA
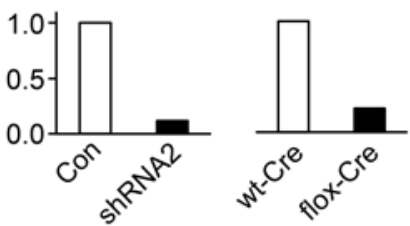
Relative Protein
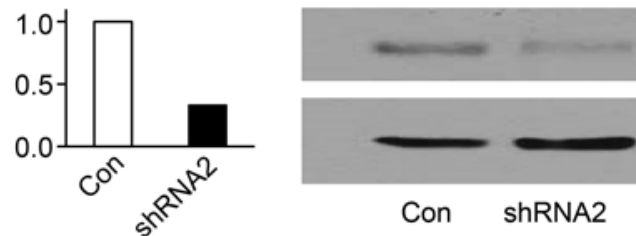

LRRC8A

GAPDH

B Expression of LRRC8A in nodose
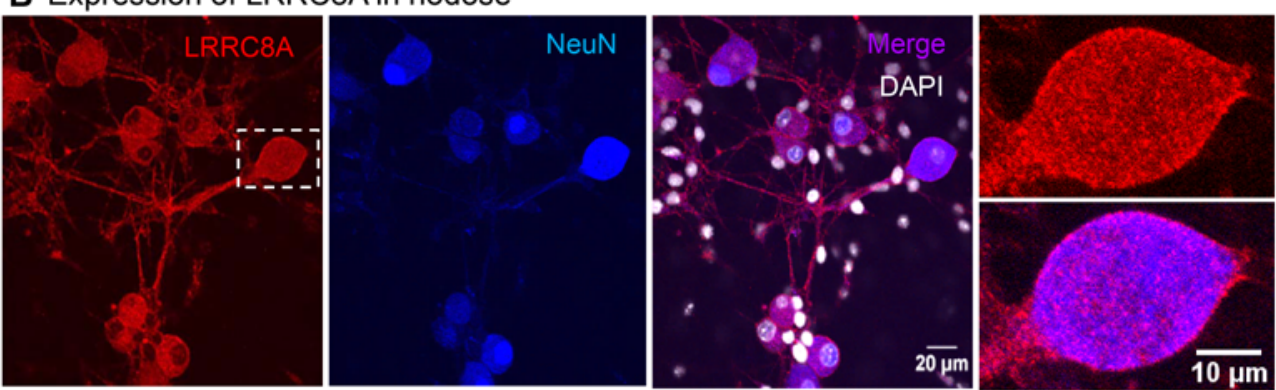

C Reduced LRRC8A fluorescence in shRNA2 transduced neurons
Con
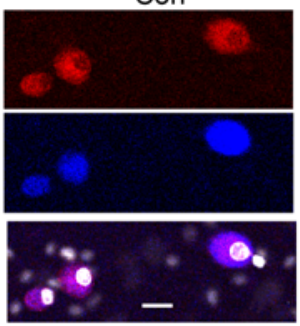

E

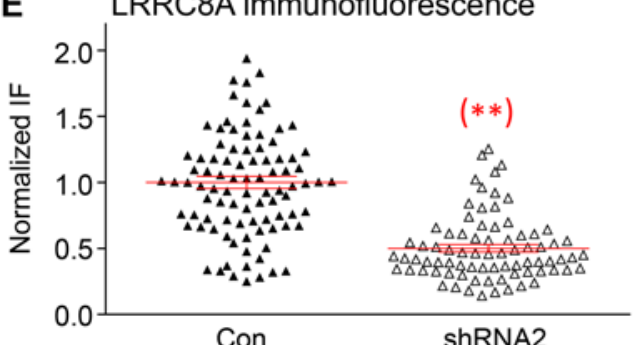

ShRNA2

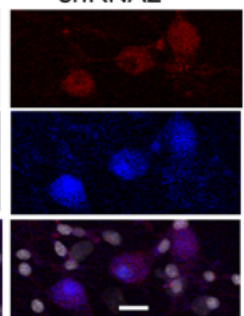

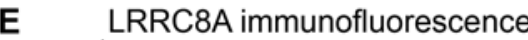

D Reduced LRRC8A fluorescence in Cre-floxed neurons
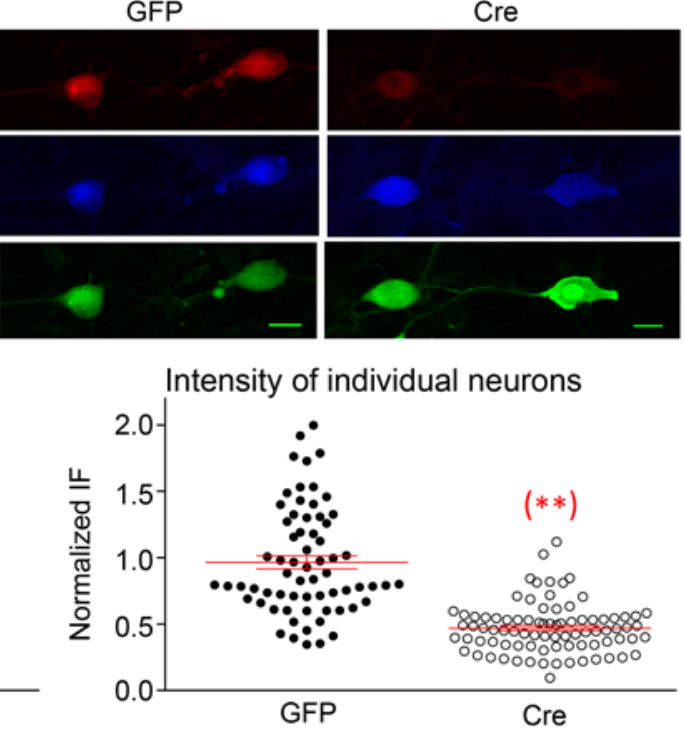

Figure 4. Expression of LRRC8A is significantly reduced in neurons transfected with shRNA2 and in Crefloxed neurons. (A) The relative mRNA of LRRC 8 A is reduced from $100 \%$ in control to $12 \%$ in shRNA2-transduced neurons and from $100 \%$ in WT-Cre to $22 \%$ in flox-Cre neurons targeting the shRNA2 sequence used (5 mice were used in each group). The relative protein is reduced from $100 \%$ in control to $33 \%$ in shRNA2-transduced neurons ( 5 mice in each group), and the Western blot result shown confirms the reduction in LRRC8A relative to GAPDH. (B) The immunofluorescence of LRRC8A (red) is expressed in the soma of nodose ganglia neurons and their neurites. The expression is colocalized with neuronal marker NeuN (blue) and is not apparent in nonneuronal cells (DAPI panel). The boxed neuron in the left panel is magnified in the 2 panels on the right to show the prominent membrane expression of LRRC8A (see also Supplemental Figure 4 for immunofluorescence of LRRC8A in membranes of HEK293 cells). (C) The red fluorescence of LRRC8A is shown in neurons transduced with control vector without shRNA (NeuN in blue, left panels). The signal of LRRC8A is reduced in neurons transduced with shRNA2 (right panels) (horizontal bars in lower panels represent $20 \mu \mathrm{m}$ ). (D) Nodose neurons from floxed mice show clear staining of LRRC8A (red) in GFP-transduced group (left panels) and reduced staining in the Cre-transduced group (right panels). Red fluorescence of LRRC8A colocalizes with the neuronal marker (blue) NeuN. (E) The normalized fluorescence intensity of LRRC8A in control neurons (Con) is reduced significantly from $1.00 \pm 0.06$ ( $n=67$ neurons from 3 mice) to $0.47 \pm 0.02$ ( $n=84$ neurons from 3 mice, ${ }^{* *} P<0.001$ ) in Cre-transduced neurons, and from $1.00 \pm 0.05$ ( $n=94$ from 2 mice) to $0.50 \pm 0.03$ ( $n=78,{ }^{* *} P<0.001$ from 2 mice) in neurons transduced with shRNA2.
Mechanism of activation of NOX by low $\mathrm{pH}_{0}$

NOX-dependent ROS generation requires the proton channel Hv1 to mediate a proton efflux mostly activated when cells are acidified and depolarized $(30,31)$. The transfer of positive charges out of the cytoplasm (i.e., alkalinity) compensates for the NOX-mediated electron extrusion and causes an intracellular shift in intracellular $\mathrm{pH}\left(\mathrm{pH}_{\mathrm{i}}\right)$ in the alkaline direction that maintains ROS generation.

This raises the question of how lowering extracellular $\mathrm{pH}_{0}$ leads to activation of NOX. One potential mechanism is that lowering of extracellular $\mathrm{pH}_{\mathrm{o}}$ generates a transient parallel drop in $\mathrm{pH}_{\mathrm{i}}$ (32), which would in turn activate the $\mathrm{Na}^{+} /$ $\mathrm{H}^{+}$exchanger and the proton channel (Hv1) causing proton efflux (33). As mentioned above, proton efflux is necessary for NOX to effectively transport electrons and generate ROS (31). Under resting conditions, $\mathrm{Na}^{+}$-dependent mechanisms (such as the $\mathrm{Na}^{+} / \mathrm{H}^{+}$exchanger) mediate acid extrusion (alkalinity) during intracellular acidification, whereas Hv1 is engaged effectively in rapid acid extrusion when cells are depolarized (30). The latter response would lead to an increase in $\mathrm{pH}_{\mathrm{i}}$ necessary to sustain the activation of NOX (34-40).

In support of this possibility, we find that clamping the normal $\mathrm{pH}_{\mathrm{i}}$ at 7.25 by increasing HEPES in the pipette to a high concentration of 40 $\mathrm{mM}$ significantly inhibits the $\mathrm{pH}_{\mathrm{o}}$-conditioned current, while the response to hypoosmolarity is preserved (Figure 7A). Thus, a change in $\mathrm{pH}_{\mathrm{i}}$ in the alkaline range is essential to induce the $\mathrm{pH}_{\mathrm{o}}$-conditioned current. 
A

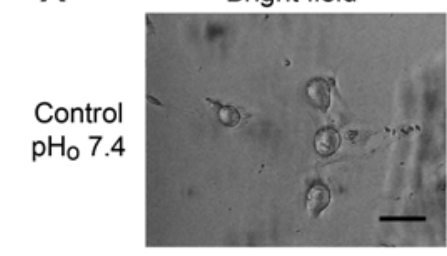

B
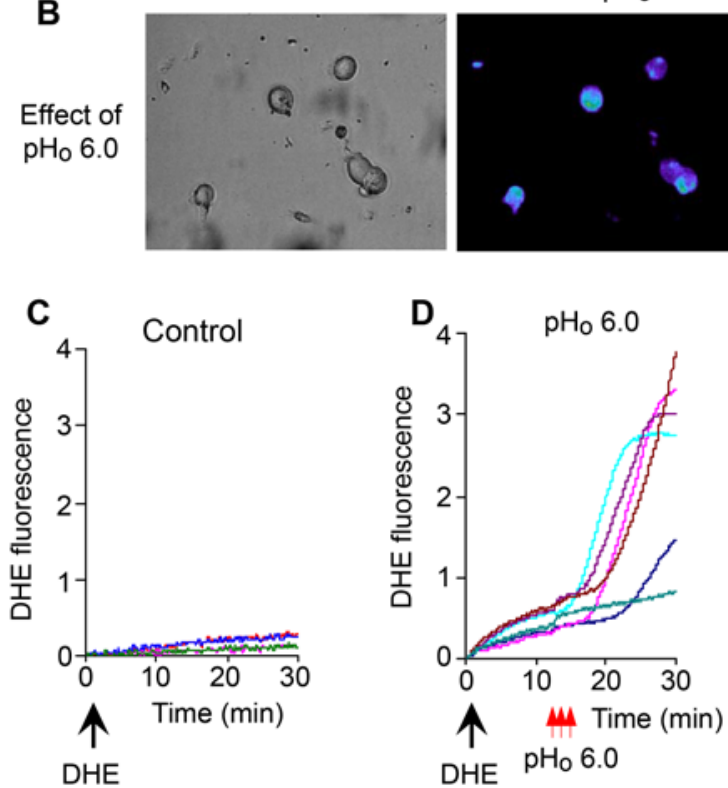

\section{DHE fluorescence}

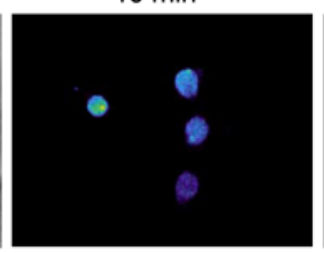

Before $\mathrm{pH}_{0} 6.0$
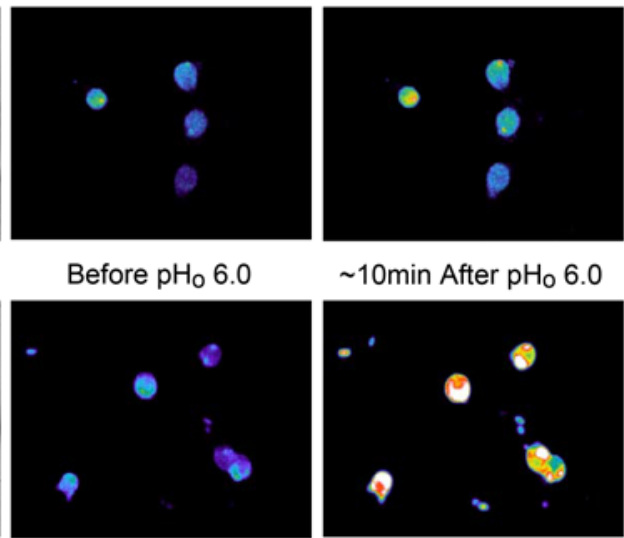

$\sim 10 \mathrm{~min}$ After $\mathrm{pH}_{0} 6.0$

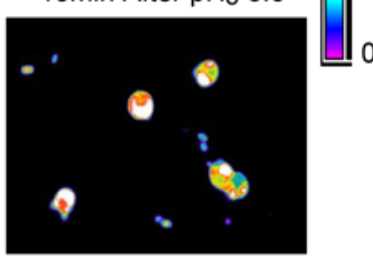

slope of

fluorescence/time

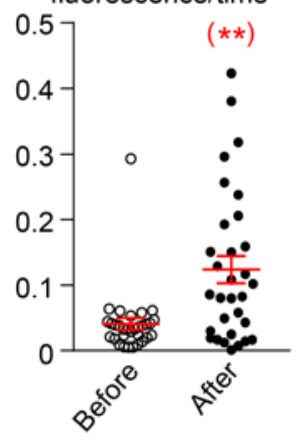

Figure 5. ROS generation during the $\mathrm{pH}_{0}$-conditioned current. The images in $\mathbf{A}$ and $\mathbf{B}$ represent the bright fields and dihydroethidium (DHE) fluorescence images of 2 different cultures of nodose neurons. (A) The cells were observed for up to 30 minutes after DHE loading in a bath solution at $\mathrm{pH}_{0} 7.4$, without exposing them to low $\mathrm{pH}_{0} 6.0$ (control). (B) The cells were loaded with DHE and then exposed transiently to $\mathrm{pH}_{0} 6.0$. The middle image shows minimal fluorescence before exposure to $\mathrm{pH}_{0} 6.0$, and the right image shows pronounced fluorescence approximately $10 \mathrm{~min}$ utes after exposure to $\mathrm{pH}_{0}$ 6.0. The corresponding graphs ( $\mathbf{C}$ and $\mathbf{D}$ ) show that after loading with DHE (large black arrows); the slope of spontaneous fluorescence seen over 30 minutes without exposure to low $\mathrm{pH}_{0}$ is minimal in $\mathbf{C}$ (control cells) as reflected in the third fluorescence image in A. (D) The slope is dramatically increased following the 3 transient exposures to $\mathrm{pH}_{0} 6.0$ (small red arrows) as reflected in fluorescence image in $\mathbf{B}$. The dot plot shows the slopes of fluorescence of individual neurons averaging $0.04 \pm 0.01$ units $/ \mathrm{min}$ before and $0.12 \pm 0.02$ units $/ \mathrm{min}$ after exposure to low $\mathrm{pH}_{0}$ ( $n=31$ neurons from 2 mice, ${ }^{* *} P<0.01$ compared with before exposure). Statistical comparison is a paired 2-tailed Student's $t$ test.

Direct measurements confirm an increase in $\mathrm{pH}_{i}$ during activation of the $\mathrm{pH}_{\mathrm{o}}$-conditioned current. To determine whether intracellular alkalinity is associated with the $\mathrm{pH}_{\mathrm{o}}$-conditioned current, we measured the change in $\mathrm{pH}_{\mathrm{i}}$ directly with the $\mathrm{pH}$-sensitive fluorescent dye 2'-7'bis(carboxyethyl)-5(6)-carboxyfluorescein (BCECF) in several neurons simultaneously (Figure 7, B and C). The average baseline $\mathrm{pH}_{\mathrm{H}}$ is $7.24 \pm 0.04(n=20)$ before low $\mathrm{pH}_{\mathrm{o}}$ exposure. We find initial transient drops in $\mathrm{pH}_{\mathrm{i}}$ with each brief extracellular exposure to solutions of low $\mathrm{pH}_{\mathrm{o}}$ of 6.0. These are not seen when the $\mathrm{pH}_{\mathrm{o}}$ of the solution is 7.4 , thus excluding mechanically induced artifacts. Following these transient drops in $\mathrm{pH}_{\mathrm{i}}$, there are sustained and prolonged increases in $\mathrm{pH}_{\mathrm{i}}$ that coincide with the duration of the $\mathrm{pH}_{\mathrm{o}}$-conditioned $\mathrm{Cl}^{-}$ current (Figure 7, C and D). This intracellular alkalinity is reversed rapidly when amiloride and $\mathrm{Zn}^{2+}$ are added (Figure 7, C and E).

Proton efflux. We next tested the dependence of the $\mathrm{pH}_{\mathrm{o}}$-conditioned $\mathrm{Cl}^{-}$current on proton efflux. Inhibiting the $\mathrm{Na}^{+} / \mathrm{H}^{+}$ exchanger with amiloride and the proton channel with $\mathrm{Zn}^{2+}$ abrogates the $\mathrm{pH}_{\mathrm{o}}$-conditioned current, whereas the hypoosmolarity-induced current is preserved (Figure 7F).

The preservation of the hyposmolarity-induced current is a positive control confirming the specificity of the effect of amiloride and $\mathrm{Zn}^{2+}$ on proton efflux and on the reversal of intracellular alkalinity. It rules out other possible direct effects of amiloride and $\mathrm{Zn}^{2+}$ on the $\mathrm{Cl}^{-}$channel that would have also suppressed the hypoosmolarity-induced current. It is important to point out that, except for the $\mathrm{kHv} 1$ proton channel in dinoflagellate (41), all Hv1 channels in vertebrates mediate proton efflux rather than proton influx and favor intracellular alkalinity, which is blocked by $\mathrm{Zn}^{2+}$.

Thus, in contrast to the $\mathrm{pH}_{\mathrm{o}}$-conditioned mechanism, which requires intracellular alkalinity and is abrogated when proton efflux is blocked, the hypoosmolar activation of NOX, which is most likely mechanically induced, does not require proton efflux or intracellular alkalinity. In experiments described in the Supplemental Material, we report that losartan, the angiotensin II AT1 receptor blocker, reduces the hypoosmolar current significantly (Supplemental Figure 5B).

$\mathrm{pH}$ dependence of $\mathrm{Cl}$ channel activation. We then found that decreases in $\mathrm{pH}_{\mathrm{i}}$ from 7.25-7.0 or 6.0 do not activate the current, whereas increases in $\mathrm{pH}_{\mathrm{i}}$ to $7.5,7.6$, or 7.8 induce significant dose-dependent activation of the current (Figure 7G. The current increases from $0.4 \pm 0.1 \mathrm{pA} / \mathrm{pF}$ at $\mathrm{pH}_{\mathrm{i}} 7.0(n=6)$ to a maximum level of $27.5 \pm 8.5 \mathrm{pA} / \mathrm{pF}$ at $\mathrm{pH}_{\mathrm{i}} 7.8(n=5)$. These data indicate that chemical activation of the $\mathrm{Cl}^{-}$channel with low extracellular $\mathrm{pH}_{\mathrm{o}}$ requires an increase in $\mathrm{pH}_{\mathrm{i}}$, which is not required during the mechanical hypoosmolar activation. In fact, the latter is pronounced at the normal acidic $\mathrm{pH}_{\mathrm{i}}(7.25)$ and is abrogated only when NOX is suppressed either by inhibition of its mechanical activation by AT1 receptor blockade or by a sustained intracellular acidity at $\mathrm{pH}_{\mathrm{i}} 6.0$ (Supplemental Figure 5, A and B). 
A Control

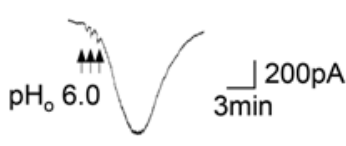

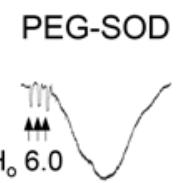

B Control
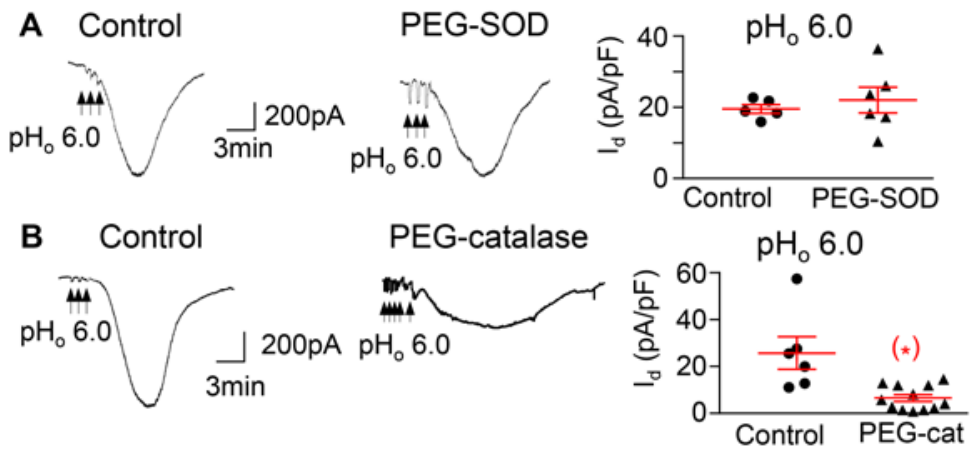

C Control

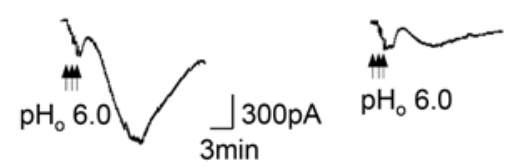

D Hypoosmolarity $(210 \mathrm{mOsm})$

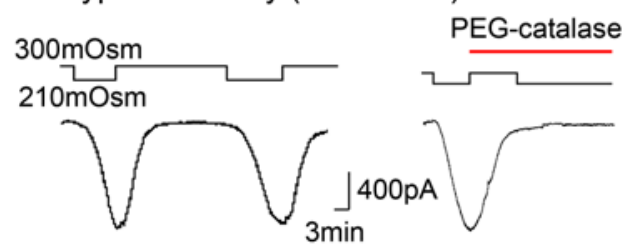

E
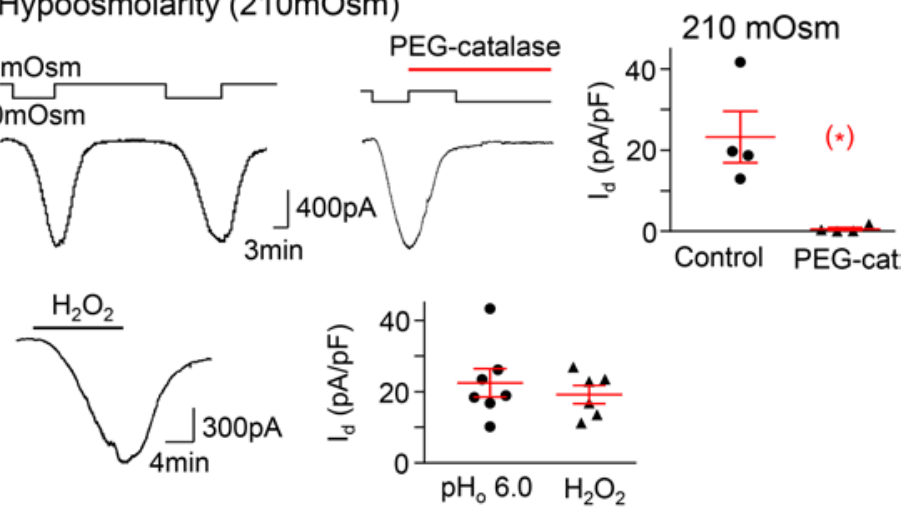

Figure 6. The $\mathrm{pH}_{0}$-conditioned $\mathrm{Cl}^{-}$current and VRAC are mediated by $\mathrm{H}_{2} \mathrm{O}_{2}$ and NADPH oxidase activation. (A) The $\mathrm{pH}_{0}$-conditioned current is not blocked by a 30-minute application of $300 \mathrm{U} / \mathrm{ml}$ of the membrane permeable superoxide dismutase-polyethylene glycol (PEG-SOD) (20 \pm 5 in control neurons, $n=3$ mice, vs. $23 \pm$ $5 \mathrm{pA} / \mathrm{pF}$ in neurons treated with SOD, $n=3$ mice); (B) the current is blocked by $1,000 \mathrm{U} / \mathrm{ml}$ of the membrane permeable PEG-catalase $(25.7 \pm 6.9$ in control neurons vs. $6.5 \pm 1.5 \mathrm{pA} / \mathrm{pF}$ in neurons pretreated with catalase; $n=4$ mice, ${ }^{*} P<0.05$ ); and (C) the current is blocked in neurons pretreated with the inhibitors of NADPH oxidase apocynin $(300 \mu \mathrm{M})$ and DPI $(30 \mu \mathrm{M})(11.5 \pm 1.9, n=3$ mice, in control vs. $3.7 \pm 0.19, n=3$ mice, with apocynin, ${ }^{* *} P<0.01$, and vs. $5.0 \pm 1.0 \mathrm{pA} / \mathrm{pF}, n=3$ mice, with DPI, $\left.{ }^{*} P<0.05\right)$. (D) The current induced by hypoosmolarity $(210 \mathrm{mOsm})$ is also blocked after exposure to PEG catalase $(1,000 \mathrm{U} / \mathrm{ml})(23.3 \pm 6.3 \mathrm{vs}$. $0.6 \pm 0.4$ $\mathrm{pA} / \mathrm{pF}$ before and after catalase, $n=2$ mice, $\left.{ }^{*} P<0.05\right)$. (E) $\mathrm{H}_{2} \mathrm{O}_{2}(1$ $\mathrm{mM})$ induces a current $(19.2 \pm 2.5 \mathrm{pA} / \mathrm{pF}, n=3$ mice) that is similar to both the $\mathrm{pH}_{0}$-conditioned ( $22.4 \pm 4.0 \mathrm{pA} / \mathrm{pF}, n=4$ mice) and hypoosmolarity-induced currents, as in $\mathbf{D}$. The panels represent responses of individual neurons and the means \pm SE of each group. Unpaired 2-tailed Student's $t$ test, except for $\mathbf{D}$, where the analysis was paired.

The low $\mathrm{pH}_{\mathrm{o}}$-conditioned current provides protective ischemic preconditioning and reduces neuronal apoptosis

It has been shown that enhanced cell volume regulation is a key protective mechanism of ischemic preconditioning (42) and that $\mathrm{Cl}^{-}$channel inhibition blocks the protection of ischemic preconditioning and hypoosmotic stress in ventricular myocardium (43). Therefore, we tested the hypothesis that the acid $\mathrm{pH}_{0}$-conditioned $\mathrm{Cl}^{-}$current is similarly protective in nodose neurons. The cultured neurons were bathed in an oxygen-deprived solution at $\mathrm{pH}_{\mathrm{o}} 5.0$, with and without glucose in the medium, for 1-3 hours to simulate an ischemic environment. There is a significant increase in lactate dehydrogenase (LDH) in the supernatant at 1 hour and a further increase at 3 hours (Figure $8 \mathrm{~A}$ ). $\mathrm{LDH}$ release is more pronounced in the absence of glucose, indicating more severe cell damage (Figure $8 \mathrm{~A}$ ). When the low $\mathrm{pH}_{\mathrm{o}}$-conditioned current is activated 10 minutes prior to the exposure to the simulated ischemia, the increases in LDH concentration in the supernatant is significantly reduced at 1 and 3 hours. The protective effect of the low $\mathrm{pH}_{\mathrm{o}}$-conditioned current is not seen when the current was inhibited by tamoxifen (10-20 $\mu \mathrm{M}$ ) (Figure 8A and Supplemental Figure 7, A and B). After tamoxifen, the enhanced LDH release after 1 and 3 hours of simulated ischemia increases to levels that are similar to those seen in the absence of low $\mathrm{pH}_{\mathrm{o}}$-conditioning (Figure 8A).

A similarly protective effect of the low $\mathrm{pH}_{\mathrm{o}}$-conditioned $\mathrm{Cl}^{-}$current is confirmed using NMDA-induced neuronal apoptosis (Figure 8B). After exposure of the cultures to $50 \mu \mathrm{M}$ of NMDA (plus $10 \mu \mathrm{M}$ glycine as a receptor coactivator) for periods of 20,40 , or 60 minutes, there are progressive increases in the number of apoptotic neurons expressed as a percentage of viable neurons over the 60 minutes. After low $\mathrm{pH}_{\mathrm{o}}$ conditioning, the corresponding number of apoptotic neurons was significantly decreased. This protective effect of the $\mathrm{Cl}^{-}$current was partially abrogated by $10 \mu \mathrm{M}$ tamoxifen as the number of apoptotic neurons increased significantly. The physiologic relevance of this neuroprotective effect against NMDA cytotoxicity is discussed below.

\section{Discussion}

We identified a large anion current induced by brief low $\mathrm{pH}_{\mathrm{o}}$ exposures in nodose neurons. We show that this current is similar to the prominent VRAC recently found to be encoded by the gene family LRRC8 (VRAC/LRRC8 or SWELL) that is induced also by hypoosmolarity $(18,19)$. Several recent studies have addressed the biophysical and physiological characterization of the VRAC (LRRC8) and its possible function beyond the regulation of cell volume (44-46). Of great interest is the recent demonstration that LRRC8 proteins that form VRAC may also sense low ionic strength in the absence of osmotic gradients (20). 
A $\mathrm{pH}_{\mathrm{i}} 7.25,40 \mathrm{mM} \mathrm{HEPES}_{\mathrm{i}}$

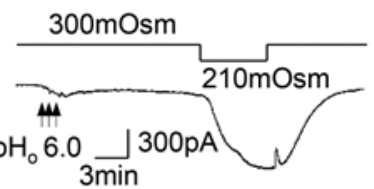

B $\mathrm{pH}$ sensitive fluorescence before $\left(\mathrm{pH}_{0} 7.4\right)$
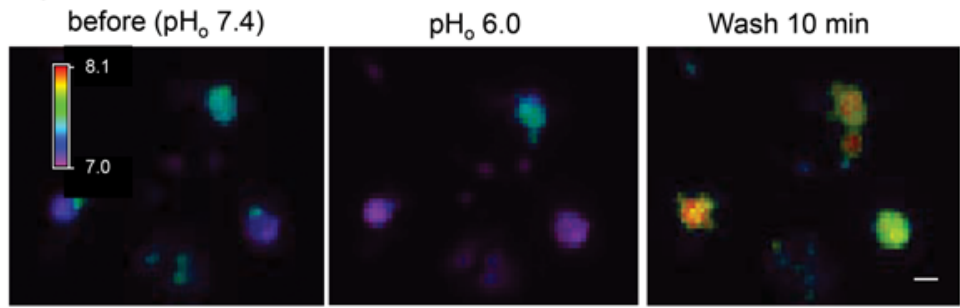

C

C Changes in intracellular $\mathrm{pH}_{\mathrm{i}}$

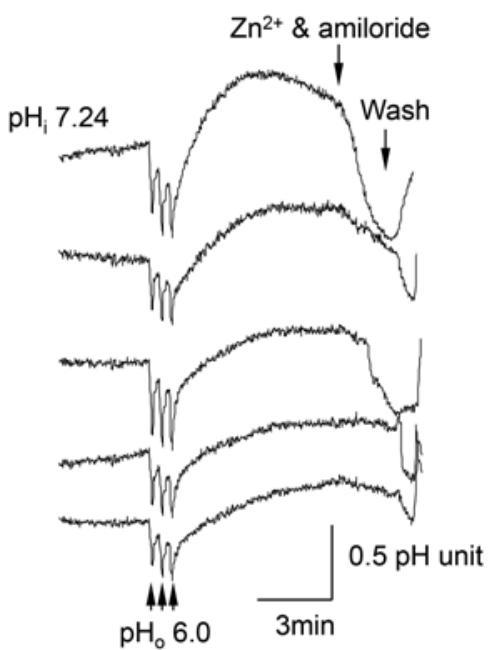

D 8.0 $\mathrm{pH}_{\mathrm{i}}$ $\mathrm{pH}_{\mathrm{i}} \quad 7$.


6.8 10mM HEPES $\triangle 40 \mathrm{mM}$ HEPES

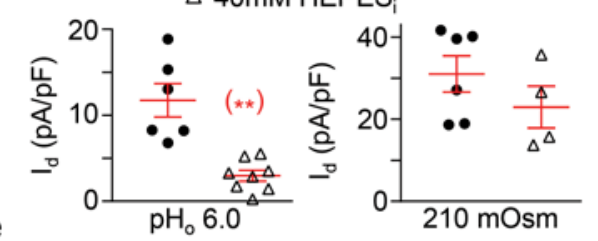

$(* *)$

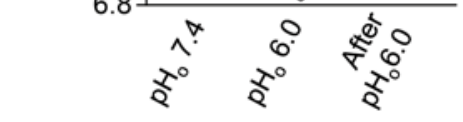

E

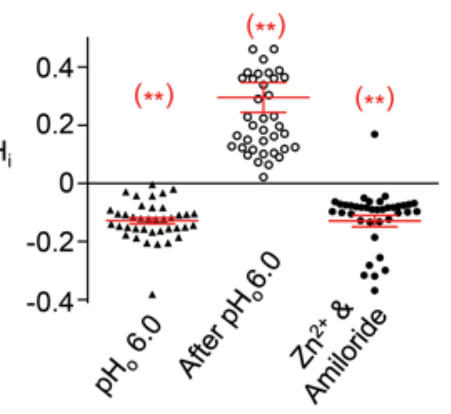

$\mathbf{F}$

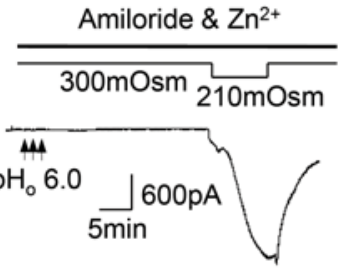

G Intracellular 40mM HEPES $\mathrm{pH}_{\mathrm{i}} 6.0 \quad \mathrm{pH}_{\mathrm{i}} 7.0 \mathrm{pH}_{\mathrm{i}} 7.25 \mathrm{pH}_{\mathrm{i}} 7.5 \quad \mathrm{pH}_{\mathrm{i}} 7.6$

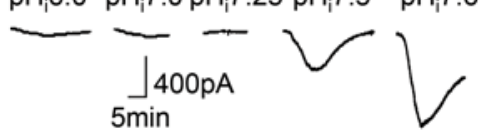

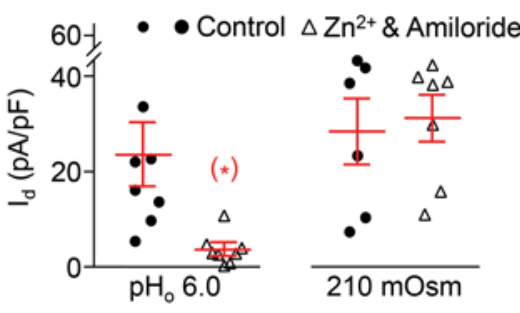

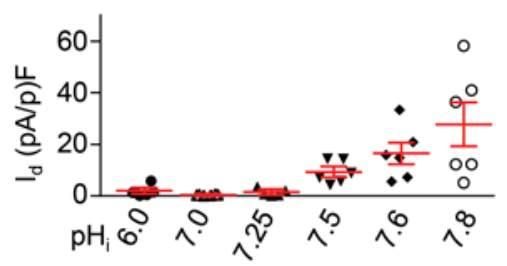

Figure 7. The $\mathrm{pH}_{0}$-conditioned $\mathrm{Cl}^{-}$current is dependent on intracellular alkalinity. (A) The $\mathrm{pH}$-conditioned current is significantly reduced when changes in $\mathrm{pH}_{\mathrm{i}}$ are buffered effectively with $40 \mathrm{mM}$ HEPES $(3.0 \pm 0.6 \mathrm{pA} / \mathrm{pF}, n=4$ mice) compared with $10 \mathrm{mM}$ HEPES $(11.8 \pm 2.0 \mathrm{pA} / \mathrm{pF}, n=4$ mice, $\left.{ }^{* *} P<0.01\right)$. However, the effect of hypoosmolarity is still preserved ( $23.7 \pm 5.1, n=2$ mice in 40mM HEPES, vs. 31.0 $\pm 4.4 \mathrm{pA} / \mathrm{pF}, n=4$ mice in $10 \mathrm{mM}$ HEPES, $P>0.05$ ). (B) The $\mathrm{pH}$-sensitive fluorescence of BCECF is changed from "blue" at $\mathrm{pH}_{0} 7.4$ (first image) to purple during exposures to $\mathrm{pH}_{0} 6.0$ (middle image) and to green, yellow, and red after the exposure (right image), reflecting variable increases in $\mathrm{pH}_{\text {. }}$. Horizontal bar in the right panel represent $20 \mu \mathrm{m}$. (C) Tracings represent changes in fluorescence recorded from 5 different neurons simultaneously first during their transient exposures to $\mathrm{pH}_{0} 6.0$ and then following the increases in $\mathrm{pH}$ to a variable degree in each neuron. Those increases are rapidly reduced when $\mathrm{Zn}^{2+}$ and amiloride are added (see arrow). (D) Normal pH of $7.2 \pm 0.04$ ( $n=40$ neurons from 3 mice at $\mathrm{pH}_{0}=7.4$ ) drops to $7.11 \pm 0.01$ ( $n=40$ neurons from 3 mice, ${ }^{* *} P<0.01$ ) during the transient exposures to $\mathrm{pH}_{0} 6.0$ and then increases to $\mathrm{pH}_{i} 7.54 \pm 0.05$ during the peak conditioned current $\left(n=40\right.$ neurons from 3 mice, ${ }^{* *} P$ $<0.001)$. (E) pH drops $\left(\Delta \mathrm{pH}_{\mathrm{i}}\right)$ by $0.13 \pm 0.01$ units $(n=40$ neurons from 3 mice, ${ }^{* *} P<0.01$ ) during exposures to $\mathrm{pH}$ 6.0 , increases by $0.29 \pm 0.05$ units ( $n=40$ from 3 mice, 2 data points not shown, ${ }^{* *} P<0.01$ ) after exposure and then rapidly declines by $0.13 \pm 0.02$ units ( $n=39$ from 3 mice, one point not shown, ${ }^{* *} P<0.01$ ) with the addition of $\mathrm{Zn}^{2+}$ and amiloride. (F) The $\mathrm{pH}_{0}$-conditioned current (black arrow) is inhibited from $23.4 \pm 6.5$ ( $n=5$ mice) to $3.6 \pm 1.1 \mathrm{pA} / \mathrm{pF}$ ( $n=4$ mice, ${ }^{*} P<0.05$ ) with amiloride and $\mathrm{Zn}^{2+}$, but the hypoosmolar-induced current remains intact $(25.9 \pm 6.3, n$ $=4$ mice, vs. $28.6 \pm 4.5 \mathrm{pA} / \mathrm{pF}, n=4$ mice, $P>0.05$ ). (G) A drop in $\mathrm{pH}_{\mathrm{i}}$ from 7.25 down to 7.0 and 6.0 does not induce a significant $\mathrm{pH}$-conditioned current, with values of $1.4 \pm 0.6$ ( $n=2$ mice), $0.4 \pm 0.1$ ( $n=2$ mice), and $1.8 \pm 0.8$ ( $n=2$ mice) $\mathrm{pA} / \mathrm{pF}$, respectively. In contrast, increases in $\mathrm{pH}_{\mathrm{i}}$ to $7.5,7.6$, and 7.8 cause progressively larger and prolonged inward currents, averaging $9.2 \pm 1.8$ ( $n=3$ mice), $16.3 \pm 4.1$ ( $n=4$ mice), and $27.5 \pm 8.5 \mathrm{pA} / \mathrm{pF}$ ( $n=3$ mice), respectively ( $P=0.021$ by ANOVA). All panels include responses of individual neurons with means \pm SE. Statistical comparisons are unpaired 2-tailed Student's $t$ test, except $\mathbf{G}$.

The low $\mathrm{pH}_{\mathrm{o}}$-conditioned activation of the VRAC that we report here requires intracellular alkalinity and an increase in intracellular $\mathrm{H}_{2} \mathrm{O}_{2}$, but whether it leads to drop in intracellular ionic strength is unknown. The pronounced and sustained low $\mathrm{pH}_{\mathrm{o}}$-induced activation of the VRAC/LRRC8 $\mathrm{Cl}^{-}$current causes significant depolarization of nodose neurons. Thus, the range of sensitivity of the LRRC8 complex in nodose neurons is expanded to include proton sensing in addi-

tion to sensing volume changes. The distribution of this $\mathrm{pH}_{\mathrm{o}}$-conditioned VRAC/LRRC 8 - not just in the majority of large and small nodose neurons but more importantly its localization by immunofluorescence in the neuronal membranes and neurites - supports its mediation of sensory signaling possibly in both $\mathrm{C}$ and A $\delta$ fibers. The expression of both the message and protein in the brain stem, as well as peripherally in the heart and small intestine, suggest its role in central mediation of vagal afferent activity. We speculate that this robust responsiveness seen in $77 \%$ of nodose neurons, which include the soma of vagal sensory terminals of most splanchnic and parenchymal organs, makes VRAC/LRRC8 a dominant peripheral low pH sensor when compared, for example, with proton-gated sensory cationic channels as ASICs and $\mathrm{K}^{+}$channels. 
A $\mathrm{LDH}$ release during simulated ischemia

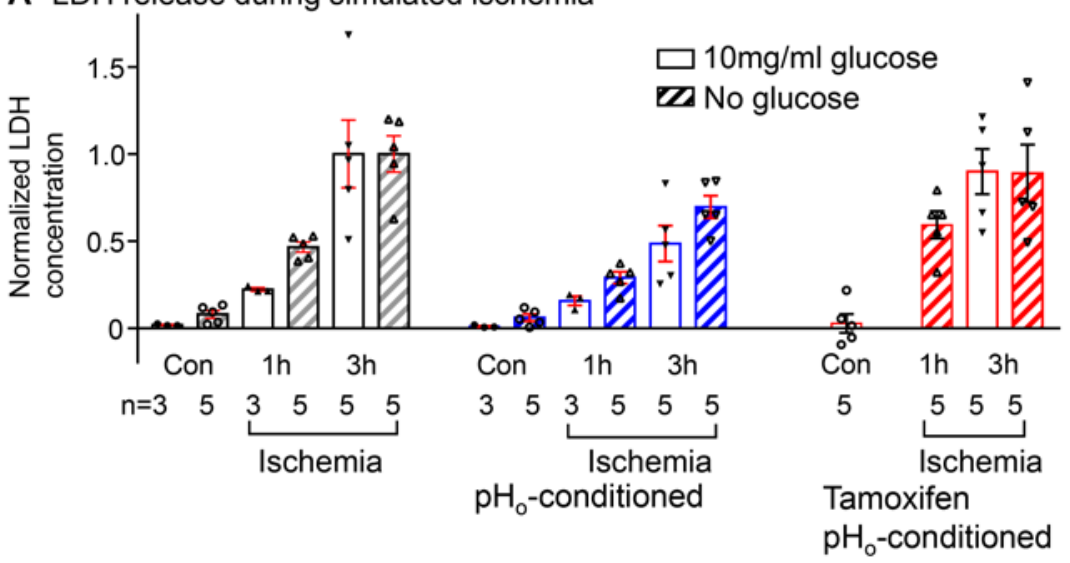

B Fluorescence of apoptotic neurons (NMDA - $60 \mathrm{~min}$ )
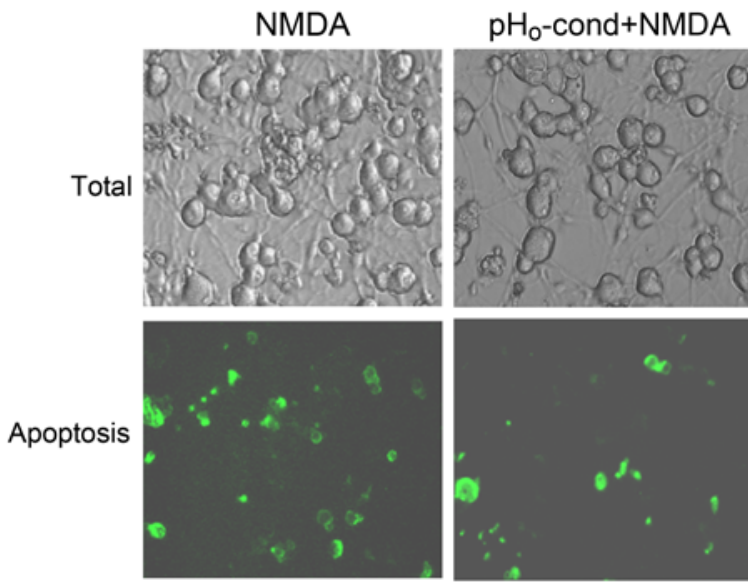

\section{Tamoxifen+} $\mathrm{pH}_{\mathrm{o}}$-cond+NMDA
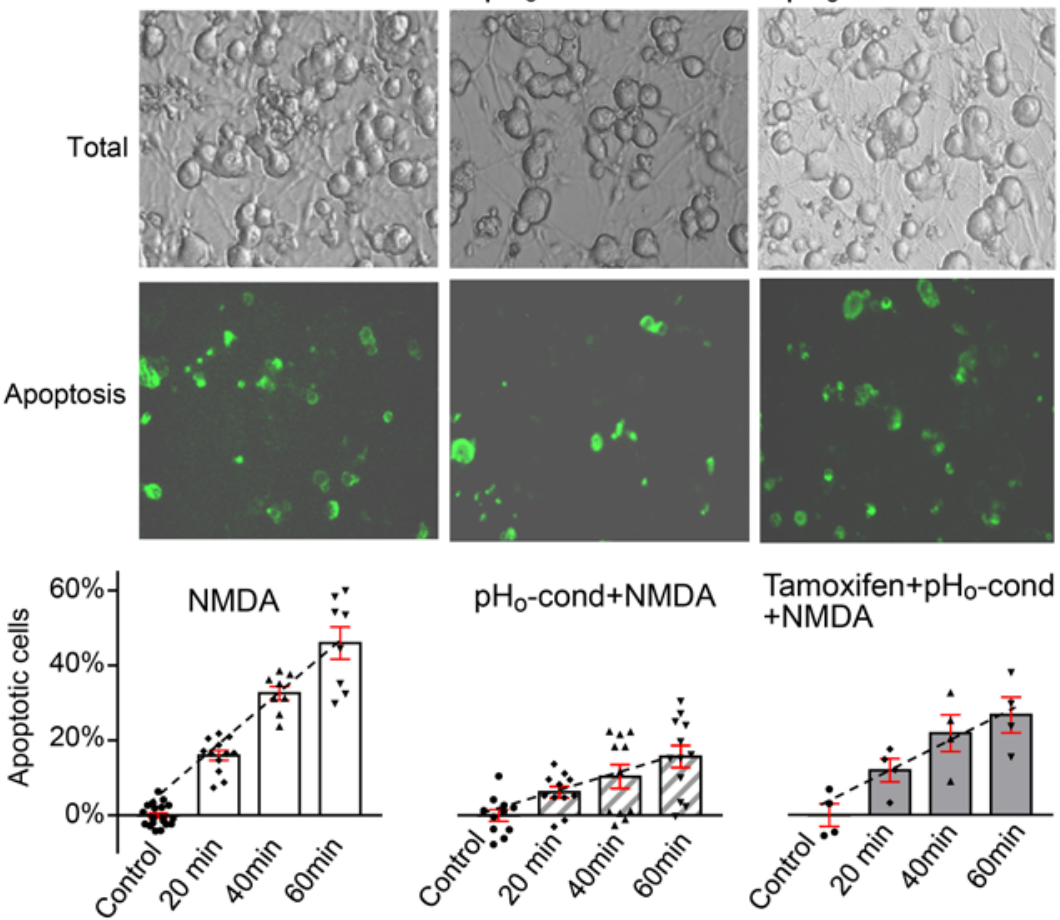

$\mathrm{pH}_{\mathrm{0}}$-cond+NMDA

Tamoxifen $+\mathrm{pH}_{\mathrm{o}}$-cond + NMDA
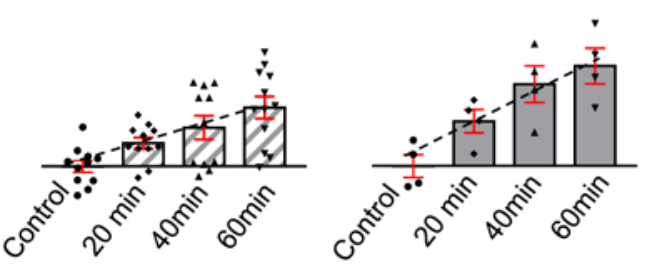

Figure 8. Protective effect of $\mathrm{pH}_{0}$-conditioned $\mathrm{Cl}^{-}$ current during simulated ischemia and NMDA-induced apoptosis. (A) Lactate dehydrogenase (LDH) release from neurons in culture over a period of 1 and 3 hours exposure to "simulated ischemia" with acidic bathing solutions $\left(\mathrm{pH}_{0} 5.0\right)$ that were oxygen deprived with glucose (open bars) or without glucose (striped bars). All responses are normalized to the mean value obtained after 3 hours of ischemia in each group ( $n=$ number of coverslips in each group). In each panel, control (Con) values were obtained over a period of 3 hours without ischemia and with or without glucose. The increase in $\mathrm{LDH}$ is negligible. The left panel shows progressive increases in LDH from $0.02 \pm 0.01$ to $0.22 \pm 0.01$ and $1.00 \pm 0.19$ at 1 and 3 hours of ischemia with glucose and from $0.08 \pm 0.02$ to $0.46 \pm 0.03$ and $1.00 \pm 0.10$ at 1 and 3 hours of ischemia without glucose. Activation of the low $\mathrm{pH}_{0}$-conditioned current (middle panel) reduces $\mathrm{LDH}$ release to corresponding values of $0.16 \pm 0.03$ and $0.48 \pm 0.10$ with glucose, and $0.29 \pm 0.03$ and $0.69 \pm$ 0.06 without glucose, at 1 and 3 hours of ischemia, respectively; $P<0.05$. When tamoxifen was added to prevent $\mathrm{pH}_{0}$ conditioning (right panel), the protective effect is totally abrogated, and LDH release during "ischemia" was restored to $0.90 \pm 0.13$ at 3 hours with glucose and to $0.59 \pm 0.08$ and $0.89 \pm 0.17$ at 1 and 3 hour without glucose. (B) Neuronal apoptosis following NMDA exposure. The images show bright fields of all neurons on individual cover slips and the corresponding green fluorescent images of the apoptotic cells labeled with annexin $\mathrm{V}$. In the absence of NMDA, there was essentially no detectable apoptosis over a period of 60 minutes (control). The percentile of apoptotic cells increased progressively to $15.9 \% \pm 1.3 \%(n=12), 32.6 \%$ $\pm 1.7 \%(n=8)$, and $46.0 \% \pm 4.3 \%(n=8)$ after exposures to NMDA for 20, 40, and 60 minutes (left panel). Following activation of the $\mathrm{Cl}^{-}$current (middle panel), the $\%$ apoptotic cells is reduced dramatically to $6.2 \% \pm$ $1.5 \%(n=11), 10.3 \% \pm 3.2 \%(n=11)$, and $15.6 \% \pm 3.1 \%$ $(n=12)$, respectively $(P<0.01)$. Tamoxifen $(10 \mu \mathrm{M})$ partially reversed the protective effect of low $\mathrm{pH}_{0}$ conditioning (right panel), and apoptosis increased to $11.9 \% \pm$ $3.1 \%(n=4), 21.6 \% \pm 4.9 \%(n=4)$, and $26.5 \% \pm 1.5 \%$ $(n=4)$ for 20, 40, and 60 minutes NMDA exposure $(P<0.01)$. Bars include responses of individual coverslips with means $\pm \mathrm{SE}$; all statistical comparisons used 2-way ANOVA.

We report that the pathways of hypoosmolarity and low $\mathrm{pH}_{\mathrm{o}}$-induced activation of VRAC in the same neuron are dependent on LRRC8. The induction of both currents involves NOX-derived $\mathrm{H}_{2} \mathrm{O}_{2}$ and is blocked by PEG catalase but not by PEG-SOD, which dismutes superoxide. Pathways of activation of VRAC/LRRC8 by low $\mathrm{pH}_{\mathrm{o}}$ and hypoosmolarity in nodose neurons appear to converge (Figure 9).

\section{Diverse mechanisms of NOX activation with low $\mathrm{pH}_{0}$ and hypoosmolarity}

An unexpected result was the similarity between these two currents. Although both currents are activated by NOX-derived $\mathrm{H}_{2} \mathrm{O}_{2}$, the mechanism of oxidase activation is likely different. Based on studies in ventricular cardiomyocytes, the volume-sensitive $\mathrm{Cl}^{-}$current is regulated by EGFR tyrosine kinase and involves integrin stretch via PI-3K and angiotensin II/ $\mathrm{AT}_{1}$ receptor signaling, resulting in the assembly of an active NOX complex $(26,47,48)$. Our results in cultured neurons suggest that hypoosmolarity may mechanically activate NOX through AT1 receptors that are blocked by losartan in the absence of angiotensin II. In a recent opinion article in Pharmacology, the ligand-independent mechanosensitivity of AT1R is extensively reviewed (49). The conformation of a mechanically activated receptor is significantly distinct from the agonist-induced conformation. The former involves mechanically induced GPCR activation via DAG and 


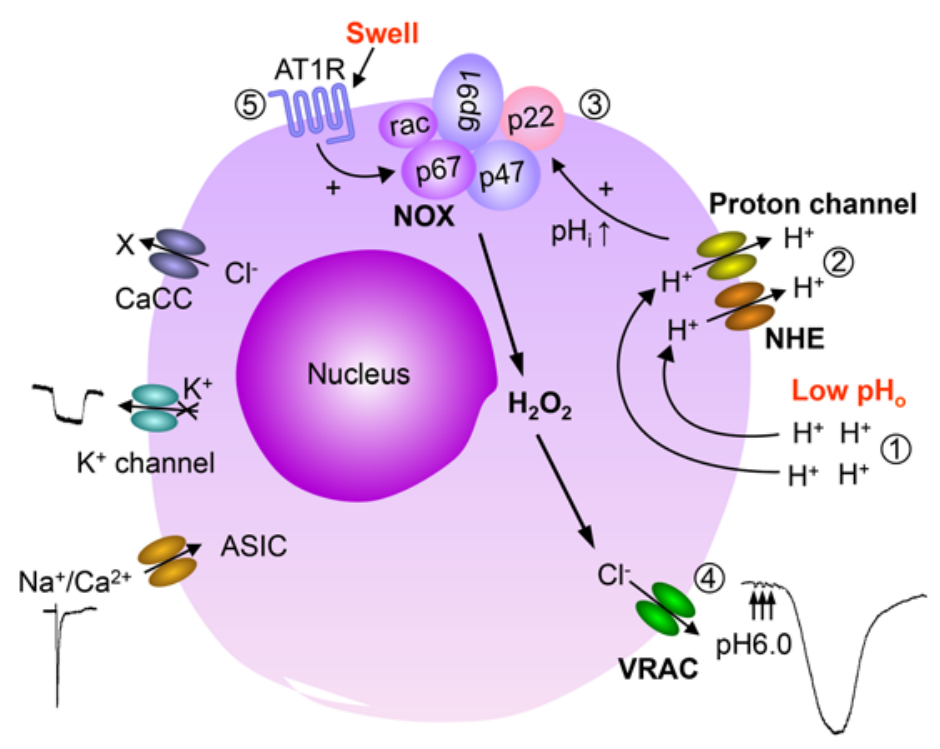

Figure 9. Schematic summary of activation mechanisms of volume-regulated anion channel (VRAC/LRRC8) by $\mathrm{pH}_{0}$ conditioning and hypoosmolarity. In nodose neuron, extracellular low pH activates transient acid-sensing ion channels (ASICs), inhibits a $\mathrm{K}^{+}$current, and activates a large and prolonged $\mathrm{pH}$-conditioned $\mathrm{Cl}^{-}$conductance similar to the VRAC/LRRC8, causing depolarization. Extracellular low $\mathrm{pH}$ induces the $\mathrm{pH}$-conditioned VRAC current by causing intracellular alkalinity. Proton leak through the plasma membrane during acidic $\mathrm{pH}$ exposures, causing a transient drop in $\mathrm{pH}_{i}$, which in turn activates $\mathrm{Na}^{+} /$ $\mathrm{H}^{+}$exchangers (NHE) and proton channels to increase $\mathrm{pH}_{\mathrm{i}^{\prime}}$. Alkalinity sustains NOX activation. The released $\mathrm{H}_{2} \mathrm{O}_{2}$ opens a pH-conditioned VRAC/LRRC8 channel (efflux of $\mathrm{Cl}^{-}$ions produces large inward currents that cause depolarization). The same VRAC is induced by hypoosmolarity believed to cause a swelling-mediated mechanical stimulation of angiotensin II $A T_{1}$ receptors ( $A T_{1} R$ ), which also activate NOX to produce $\mathrm{H}_{2} \mathrm{O}_{2}$. The dual NOX activation by intracellular alkalinity or by stimulation of $\mathrm{AT}_{1} \mathrm{R}$ mediates a prolonged and pronounced $\mathrm{Cl}^{-}$efflux and membrane depolarization of nodose neurons. Activation of this $\mathrm{pH}_{\mathrm{o}}$-conditioned current reduces neuronal ishemic damage and NMDA-induced apoptosis. Thus, VRAC/LRRC8 provides dual sensory neuroprotective effect for vagal afferents against low $\mathrm{pH}$ and cell swelling. $\mathrm{CaCC}, \mathrm{Ca}^{2+}$-dependent $\mathrm{Cl}^{-}$channels.

PKC and the assembly of NOX and ROS generation (50), which in turn activates VRAC. Moreover, we find that a sustained increase in intracellular acidification also abrogates the mechanically induced NOX activation during hypoosmolarity believed to be initiated by $\mathrm{AT}_{1}$ receptors (Supplemental Figure 5, A and B). The mechanisms involved in this inhibition of the hypoosmolar mechanical stimulus in nodose neurons are unclear.

Effect of intracellular $\mathrm{pH}$. In contrast to the hypoosmolar response, the low $\mathrm{pH}_{\mathrm{o}}$-induced activation of NOX in nodose neurons required a paradoxical increase in $\mathrm{pH}_{\mathrm{i}}$. The latter appears to result from activation of $\mathrm{Na}^{+} / \mathrm{H}^{+}$exchangers and proton channels induced by a transient initial drop in $\mathrm{pH}_{\mathrm{i}}$ (Figure $7 \mathrm{C}$ ). These data are consistent with reports that sustained activation of NOX requires proton efflux and intracellular alkalinity. Prevention of that efflux with amiloride and $\mathrm{Zn}^{2+}$ abrogates the $\mathrm{pH}_{\mathrm{o}}$-induced current by reversing the alkalinity.

Although the $\mathrm{pH}_{\mathrm{i}}$ measurements were in intact neurons and the currents were measured in patchclamped neurons, we believe that directional changes in $\mathrm{pH}_{\mathrm{i}}$ were similar for 3 reasons: (i) when intracellular buffering of changes in $\mathrm{pH}_{\mathrm{i}}$ was maximal (40 mM HEPES), the acid-induced current was inhibited, but the hypoosmolarity response was fully preserved as a "positive control," meaning low $\mathrm{pH}_{\mathrm{o}}$ activation requires a change in $\mathrm{pH}_{\mathrm{i}}$ (see Figure 7A); (ii) when $\mathrm{pH}_{\mathrm{i}}$ was changed in Figure 7G to cover the range of changes seen in the intact cell (Figure 7C), the current was activated in the alkaline range of 7.5-7.8 and inhibited at 7.25 and below, meaning the current activation in the patch-clamped neurons occurs in an alkaline range that paralleled the measured alkaline $\mathrm{pH}_{\mathrm{i}}$ seen in the intact cells (see Figure 7, $\mathrm{C}$ and $\mathrm{G}$ ); and (iii) the inhibitors of proton efflux (amiloride and $\mathrm{Zn}^{2+}$ ) lowered the $\mathrm{pH}_{\mathrm{i}}$ in the intact cells to a range that inhibited the induction of the current as anticipated.

The possibility exists that the nonspecific effects of amiloride and/or $\mathrm{Zn}^{2+}$ on other channels and transporters may have contributed to the abrogation of the $\mathrm{pH}_{\mathrm{o}}$-induced current seen in their presence in Figure 7F. However, the selective inhibition of the $\mathrm{pH}_{\mathrm{o}}$-induced current and not the hypoosmolarity current suggests a more specific effect.

\section{Intracellular Cl concentration in central vs. peripheral neurons}

The peak current in nodose neurons represented a large $\mathrm{Cl}^{-}$efflux that was maintained in the absence of $\mathrm{Na}^{+}, \mathrm{Ca}^{2+}$, and $\mathrm{K}^{+}$. To consider its functional significance, an important caveat needs to be addressed. The magnitude of the $\mathrm{pH}_{\mathrm{o}}$-conditioned $\mathrm{Cl}^{-}$efflux would be dependent on a high intracellular $\mathrm{Cl}^{-}$concentration, yet the majority of CNS neurons possess a uniformly low intracellular $\mathrm{Cl}^{-}$concentration $(\sim 3 \mathrm{mM})$, which facilitates $\mathrm{Cl}^{-}$influx as the basis for GABAergic and glycinergic inhibition. This low $\left[\mathrm{Cl}^{-}\right]_{i}$, which is referred to as the $\mathrm{Cl}^{-}$switch, occurs postnatally and primarily in CNS neurons, while peripheral sensory neurons retain a higher though heterogeneous level of $\left[\mathrm{Cl}^{-}\right]_{\mathrm{i}}$ (for example, olfactory neurons have a $[\mathrm{Cl}]_{\mathrm{i}}$ of $40-50$ 
$\mathrm{mM}$, and somatosensory DRG neurons have a $[\mathrm{Cl}]_{\mathrm{i}}$ of $50-60 \mathrm{mM}$; ref. 25). The activity of $\mathrm{Na}^{+} / \mathrm{K}^{+} / 2 \mathrm{Cl}^{-}$ and KCC cotransporters maintains the high $\left[\mathrm{Cl}^{-}\right]_{\mathrm{i}}$ and supports an important excitatory contribution of $\mathrm{Cl}^{-}$efflux, as reported in spinal afferents $(24,25)$ and as we have identified in nodose neurons.

In preliminary experiments aimed at contrasting responses to low $\mathrm{pH}_{\mathrm{o}}$ conditioning in DRG to those in NG neurons, we found that, in DRG neurons, the $\mathrm{Cl}^{-}$current was not induced during low $\mathrm{pH}_{\mathrm{o}}$ but was induced with hypoosmolarity (Figure 3E). Gilbert et al. have described extensively $\mathrm{Cl}$ homeostasis in somatosensory DRG neurons (25). They suggest that the measured $\mathrm{Cl}^{-}$equilibrium potential $\left(\mathrm{E}_{\mathrm{Cl}}\right)$ values (around $-40 \mathrm{mV}$ ) limit the excitatory effect of $\mathrm{Cl}^{-}$current and may even oppose strong depolarization and excitation. Secondly, they indicate that NKCC1 (the transporter critical for intracellular $\left[\mathrm{Cl}^{-}\right]_{\mathrm{i}}$ ) can be detected in $84 \%$ of DRG somatosensory neurons. This expression pattern may indicate that excitatory $\mathrm{Cl}^{-}$ currents may be restricted to certain modalities of the sensory system. The excitatory or inhibitory nature of $\mathrm{Cl}^{-}$current varies between distinct populations of neurons based on the $\mathrm{E}_{\mathrm{Cl}}$ range, which varies from -70 to $-20 \mathrm{mV}$ and on $\left[\mathrm{Cl}^{-}\right]_{\mathrm{i}}$ near 40,60 , or $80 \mathrm{mM}$. Even in the same population of neurons (i.e., nodose neurons), the magnitude of depolarization with $\mathrm{pH}_{\mathrm{o}}$ conditioning was based on the equilibrium potential of $\left[\mathrm{Cl}^{-}\right]$as we report in Figure $1 \mathrm{C}$.

Moreover, the neuronal site at which NKCC1 localizes may define the responsiveness. Price et al. (51) found that the $\mathrm{NKCCl}$ displays $\sim 50 \%$ colocalization with markers of unmyelinated nociceptors (15-35 $\mu \mathrm{m})$. Only $10 \%-20 \%$ colocalize with markers for myelinated low-threshold sensory neurons of larger size $(25-55 \mu \mathrm{m})$. Thus, different $\left[\mathrm{Cl}^{-}\right]_{\mathrm{i}}$ may determine the responsiveness to different signals (e.g., mechanical, low $\mathrm{pH}$, nociception, temperature, and hypoxia).

In several conditions, including hypoxic ischemic injury and prolonged seizures, neuronal swelling is associated with an increase in neuronal $\left[\mathrm{Cl}^{-}\right]_{\mathrm{i}}$. For example, a 10\% seizure-induced increase in neuronal volume causes an increase in $\left[\mathrm{Cl}^{-}\right]_{\mathrm{i}}$ from $25.4-40.8 \mathrm{mM}$ (52). Our results with the $\mathrm{Cl}^{-}$-impermeable ionophore gramicidin confirm a substantial $\mathrm{pH}_{\mathrm{o}}$-conditioned sustained $\mathrm{Cl}^{-}$-dependent depolarization of $12.7 \pm 3.4$ $\mathrm{mV}$ in $\mathrm{NG}$ neurons at physiologic $\left[\mathrm{Cl}^{-}\right]_{\mathrm{i}}$ (Figure $\left.1 \mathrm{C}\right)$.

Another aspect of the results is the prolonged duration of the $\mathrm{Cl}$ response lasting over 10-15 minutes following exposure to low $\mathrm{pH}_{\mathrm{o}}$ for a total period of 30 seconds. This suggests a degree of neuronal plasticity that may be involved in processes like ischemic preconditioning. The fact that the $\mathrm{pH}_{\mathrm{o}}$-conditioned current is regulated by ROS, in particular $\mathrm{H}_{2} \mathrm{O}_{2}$, supports the emerging evidence that $\mathrm{H}_{2} \mathrm{O}_{2}$ is a molecular determinant in these same processes (53-55)

\section{Neuroprotective role of the volume-regulated $\mathrm{Cl}^{-}$current and its $\mathrm{pH}_{0}$-conditioned activation in nodose sensory neurons}

A constant cell volume is essential for cellular homeostasis during changes in osmolarity. The ubiquitous swell-activated VRAC plays a key role in maintaining cellular integrity. Studies in rabbit ventricular myocyte demonstrated that a $\mathrm{Cl}^{-}$channel that enhances cell volume regulation provides a key protective mechanism of ischemic preconditioning (42). Conversely, the same authors showed that $\mathrm{Cl}^{-}$channel inhibition blocks the protection of ischemic preconditioning and hypoosmotic stress in rabbit ventricular myocardium (43). It is also known that ROS generation is required for ischemic cardiac preconditioning (56). Our findings that exposure of nodose neurons to low $\mathrm{pH}_{\mathrm{o}}$, as well as to hypoosmolarity, activates a $\mathrm{Cl}^{-}$current and that low $\mathrm{pH}_{\mathrm{o}}$ generates ROS suggest that this current may also mediate ischemic preconditioning in nodose neurons. Also of interest is our finding that the initial exposure to low $\mathrm{pH}_{\mathrm{o}}$ that induced the $\mathrm{Cl}^{-}$current abrogated responses to subsequent low $\mathrm{pH}_{\mathrm{o}}$ exposures (Supplemental Figure $3 \mathrm{C}$ ), whereas the response to hypoosmolarity could be reproduced with several subsequent exposures. This suggests that the $\mathrm{pH}_{\mathrm{o}}$ preconditioning prevents further low $\mathrm{pH}_{\mathrm{o}}$ response selectively and may protect against ischemic damage in the absence of cell swelling and without altering the hypoosmotic response.

This functional neuroprotective role was evident following the brief period of activation of the low $\mathrm{pH}_{\mathrm{o}}$-conditioned $\mathrm{Cl}^{-}$current that was very effective in reducing $\mathrm{LDH}$ release from nodose neurons during their exposure to simulated ischemia and the absence of aerobic glycolysis for 3 hours. The protective effect against NMDA-induced apoptosis was even more pronounced. The increase in apoptotic cells, which was linearly related to increased durations of exposures to NMDA for up to 60 minutes, was reduced by $2 / 3$ over a 20-hour period following the activation of the $\mathrm{Cl}^{-}$current. Such a putative preconditioning of vagal sensory neurons would reduce neuronal apoptosis and maintain protective vagal afferent activity during myocardial ischemia and heart failure (57-59). 
Glutamate is a major neurotransmitter released from the axonal connections of nodose neurons in the nucleus of the solitary tract (NTS). NMDA receptors are also expressed in sensory endings of nodose neurons that may be activated by glutamate released from innervated organs. For example, glutamate release has been reported from the ischemic myocardium (60) and may activate cardiac vagal afferents. In a recent article by Gaitán-Peñas et al., (61) the authors demonstrated that LRRC8 heteromers mediate both glutamate and ATP flux. It is tempting to speculate that the neuroprotective effect of the $\mathrm{pH}_{\mathrm{o}}$-induced current during exposure to NMDA or simulated ischemia, as well as the ischemic preconditioning of ventricular myocardium reported during hypoosmolar swelling by Diaz et al. $(42,43)$, may be in part related to the flux of glutamate and ATP through the activated LRRC8/VRAC channel. This flux may function as a protective reuptake mechanism reducing glutamate levels and glutamate-induced toxicity.

\section{Caveats regarding the interpretation of our results}

LRRC8/SWELL1 has thus far been confirmed as an essential component of the hypoosmolar response of the VRAC channel in HEK293, HEK29T, HCT116, HeLa cell lines, and primary human CD4+ T lymphocytes $(18,19)$. It remains open whether the dual activation of VRAC that we report with hyposmolarity and low $\mathrm{pH}_{\mathrm{o}}$-conditioning is specific for NG. Our results in HEK293 and DRG neurons indicate that the VRAC in these cell types responds to hypoosmolarity but not to $\mathrm{pH}_{\mathrm{o}}$ conditioning. Direct delivery of intracellular alkaline $\mathrm{pH}$ activated the VRAC current in nodose neurons but not in the DRG neurons or the HEK293 cells (Supplemental Figure 6). The lack of response to alkalization excludes a possible lack of the $\mathrm{Na}^{+} / \mathrm{H}^{+}$ exchanger or proton channel in DRG or HEK cells as the reason for their failure to respond to low $\mathrm{pH}$. The reason for the lack of $\mathrm{pH}_{\mathrm{o}}$-conditioned activation is unclear. The fact that intracellular alkalinity does not induce the current in DRG as in NG neurons suggests a possible differential effect on NOX activation.

Of interest is that, in the minimalistic bilayer system, a complex of the LRRC8 family is sufficient to form the VRAC pore that senses both hyposmolarity and ionic gradient (20). It is possible that different heteromeric expression of the several subunits of LRRC8 proteins besides $8 \mathrm{~A}$ that form the hexamer might account for a differential response of the channel to either hypoosmolarity or $\mathrm{pH}_{\mathrm{o}}$ in different cells or neurons from different ganglia. It is also possible that the formation of a heteromeric VRAC channel in the native environment may require additional components than the LRRC8 family to enable the $\mathrm{pH}$ sensing in addition to hypoosmolarity sensing. These additional components may vary in different cell systems, allowing the VRAC to sense additional signals.

\section{Methods}

More detailed methods can be found online in Supplemental Methods.

\section{Dissociation and Acute Culture of Neurons and HEK293 Cells}

NG and DRG were dissociated as described previously (5). In brief, the ganglia were dissected from 6- to 8-week-old C57BL/ 6 mice (The Jackson Laboratory). They were incubated in enzyme cocktail containing trypsin and collagenase for 50-60 minutes at $37^{\circ} \mathrm{C}$ and then triturated. The digestion was then stopped with enzyme inhibitor, and neurons were then collected and transferred to glass cover slips coated with poly-Llysine. Euthanasia was performed following the guidelines of NIH/American Physiologic Society (APS).

HEK293 cell line was obtained from American Type Culture Collection (ATCC CRL-1573). Cells were maintained between $10 \%-90 \%$ confluence in a tissue culture incubator with $37^{\circ} \mathrm{C}$ and $5 \% \mathrm{CO}_{2}$.

\section{Electrophysiology}

Whole-cell patch clamp technique was employed as described previously in reports from our laboratory (62) and others (3). Patch pipettes with resistance of 3-5 M $\Omega$ were filled with intracellular solutions. Rapid exchanges in bath solutions allowed the extracellular changes in ionic concentrations, $\mathrm{pH}$, and osmolarity and the delivery of pharmacologic blockers. Electrophysiologic voltage and current measurements were recorded with Clampex 8.2 and analyzed with Clamfit 9.2 (Axon Instruments).

\section{Activation of the low $\mathrm{pH}_{0}$-conditioned current}

Neurons in culture were first washed with normal solution at $\mathrm{pH} 7.4$; then, the solution was changed to $\mathrm{pH}_{\mathrm{o}} 6.0$ for 10 seconds, followed by a return to the $\mathrm{pH}_{\mathrm{o}} 7.4$ solution for 20 seconds. In our standardized protocol, the exchange to $\mathrm{pH}_{\mathrm{o}} 6.0(10 \mathrm{sec})$ and to $\mathrm{pH}_{\mathrm{o}} 7.4(20 \mathrm{sec})$ was repeated 2 more times. The 
neurons were then maintained at $\mathrm{pH}_{\mathrm{o}} 7.4$ while the inward current was recorded over the subsequent 10-15 minutes (Figure 1, A and B).

The rationale for the 3 pulses for low $\mathrm{pH}_{\mathrm{o}}$ is as follows. In several of the earliest experiments, the large and prolonged $\mathrm{Cl}^{-}$current was seen in neurons after only one brief $(10 \mathrm{sec})$ exposure to a low $\mathrm{pH}$ pulse followed by restoration of the neutral $\mathrm{pH}$. Other neurons did not evoke the current after only one 10s-second low $\mathrm{pH}$ exposure but did so after a second or third low $\mathrm{pH}$ pulse. In order to standardize the stimulus and determine the maximal number of putative neurons that might evoke the current, we opted for 3 consecutive brief low $\mathrm{pH}$ pulses. Following the 3 pulses and restoration of neutral extracellular $\mathrm{pH}$ (7.4), the prolonged $\mathrm{Cl}^{-}$current that we referred to as the $\mathrm{pH}$-conditioned current was seen in nearly $80 \%$ of NG neurons.

\section{Detection of ROS}

Coverslips of cultured NG neurons were mounted in a closed perfusion chamber on the inverted fluorescence microscope and then loaded with $10 \mu \mathrm{M}$ DHE at room temperature (Invitrogen). Fluorescence of DHE was excited at wavelengths of $535 \pm 50 \mathrm{~nm}$ and monitored at $610 \pm 75 \mathrm{~nm}$.

\section{$\mathrm{pH}_{\mathrm{i}}$ measurement}

The $\mathrm{pH}_{\mathrm{i}}$ of nodose ganglion neurons was monitored with cytoplasmic $\mathrm{pH}$-sensitive fluorochrome BCECF-AM (Molecular Probes) as reported previously (63). Neurons cultured on coverslips were loaded with 2 $\mu \mathrm{M}$ BCECF in HBSS for 5 minutes. Fluorescence of BCECF was excited at wavelengths of $495 \mathrm{~nm}$ and 440 $\mathrm{nm}$ and monitored at a wavelength of $530 \mathrm{~nm}$. The calibration of $\mathrm{pH}_{\mathrm{i}}$ was obtained using nigericin $(30 \mu \mathrm{M})$ and high $\mathrm{K}^{+}$buffer. The ratiometric fluorescence was calculated as $\mathrm{F}_{\text {ratio }}=\left(\mathrm{F}_{495}-\mathrm{F}_{0495}\right) /\left(\mathrm{F}_{440}-\mathrm{F}_{0440}\right)$, where $\mathrm{F}_{0}$ refers to fluorescence intensity at baseline.

Although amiloride is intrinsically fluorescent, it did not influence the measurement of intracellular alkalinity with $\mathrm{BCECF}$, since it was added to the neurons in culture after the peak increase in $\mathrm{pH}_{\mathrm{i}}$. Moreover, the excitation and emission wavelengths for amiloride are 362 and $415 \mathrm{~nm}$ and differ significantly from those of BCECF (64).

\section{Neuroprotective effect of the $\mathrm{pH}_{0}$-conditioned $\mathrm{Cl}^{-}$current}

Two approaches were utilized to inflict neuronal damage: simulated ischemia and the induction of apoptosis with NMDA and glycine.

$L D H$ during simulated ischemia. Oxygen deprivation and acidosis are hallmarks of ischemia. Cultured neurons were incubated for 1-3 hours in acidic bathing solutions $\left(\mathrm{pH}_{\mathrm{o}} 5.0\right)$ that were oxygen deprived (in a chamber filled with $95 \% \mathrm{~N}$ and $5 \% \mathrm{CO}_{2}$ at $36^{\circ} \mathrm{C}$ ) to simulate ischemia and were either without glucose or with glucose $(20 \mathrm{mM})$. LDH release was measured in $100 \mu 1$ aliquots of the supernatant fluid after 1 and 3 hours of incubation. The responses to simulated ischemia were measured under 3 conditions: (i) without activation of the $\mathrm{pH}_{\mathrm{o}}$-conditioned $\mathrm{Cl}^{-}$current; (ii) following activation of the $\mathrm{Cl}^{-}$current; and (iii) with tamoxifen in the bath solution during activation of the low $\mathrm{pH}_{\mathrm{o}}-$ conditioned current. Tamoxifen $(20 \mu \mathrm{M})$ was added 10 minutes before $\mathrm{pH}_{\mathrm{o}}$ conditioning and retained for another 10 minutes before exchanging the normal bathing solution with the ischemic solution without tamoxifen.

Apoptotic effect of NMDA. Exposure of nodose neurons in culture to $50 \mu \mathrm{M}$ NMDA for 20, 40, and 60 minutes caused a progressive increase in the number of apoptotic cells identified by using Alexa Fluor 488 Annexin V labeled with a fluorophore that binds to phosphatidyl serine. The phosphatidyl serine is translocated to the outer surface of the plasma membrane during apoptosis. Within 20 hours following the exposure to NMDA, a significant percentage of cells became apoptotic. The degree of NMDA-induced apoptosis was tested under 3 different conditions: (i) without activation of the acid $\mathrm{pH}_{\mathrm{o}}$-conditioned $\mathrm{Cl}^{-}$current; (ii) after the activation of the $\mathrm{Cl}^{-}$current; and (iii) after tamoxifen was added to the culture to block the $\mathrm{Cl}^{-}$current.

\section{Lentiviral shRNA to knockdown LRRC8A}

Two lentiviral shRNAs targeting different sequence regions of LRRC8A mRNA (GenBank ReSeq: NM_001127245.1) were used in this study. These are referred to as shRNA1 and shRNA2. These lentiviruses also confer puromycin resistance to the transduced cells. The details of lentivirus production are provided in Supplemental Materials. Nodose neurons were challenged with shRNA lentivirus particles in cultures. Virus transduced neurons were selected for puromycin resistance and channel activities record- 
ed. These methods are detailed in the Supplemental Materials. The knockdown efficiencies of lentiviral shRNAs and LRRC8A mRNA and proteins were assessed using qPCR and Western blotting (please refer to the Supplemental Methods for details).

\section{CRISPR-Cas9 mediated KO of LRRC8A in HEK cells}

A double-guide KO approach was used to generate LRRC8A-null gene in HEK 293 cells. Guide sequences designed based on previously published work, as well as Web-based CRISPR design tool (http://crispr.mit. edu/) were cloned in a bicistronic vector expressing cas9 (pSpCas9(BB)-2A-Puro). The guides were transfected into HEK 293 cells using Lipofectamine 2000 as per manufacturer's instructions.

\section{qPCR}

Total RNA was extracted from the mouse tissues by using Trizol reagent (Invitrogen). Obtained RNAs were treated with DNase Treatment Kit (Qiagen) and further purified. The RNAs were reverse transcribed into cDNA by using AffinityScriptTM QPCR cDNA Synthesis Kit (Invitrogen) according to the manufacturer. The quantitative analysis of the mRNA expression was carried out by using Model 7000 real-time PCR system (Applied Biosystems, model 7000). Brilliant SYBR Green QPCR Master Mix (Invitrogen) and primers were used according to the protocol provided by the manufacturer. The expression of $18 \mathrm{~S}$ ribosomal RNA was used to normalize the measurements. qPCR was performed using the following specific primers for LRRC8A gene that were designed in our laboratory (Forward: 5'-GGC CGT CAC AGC CAA TAG GA-3', Reverse: 5'-TCG ATC TGC GTC AGG TTG GT-3'). The $\triangle \Delta$ CT method was applied for the data analysis.

\section{Western blots}

Six NG from 3 mice were homogenized, vortexed, and sonicated; $60 \mu \mathrm{g}$ protein was denatured and run on a 10\% Ready Gel Tris- $\mathrm{HCl}$ gel (Bio-Rad). The proteins in gel were then transferred to nitrocellulose membrane (ThermoFisher Scientific). Membrane was blocked with 5\% nonfat milk and then incubated with the primary rabbit anti-LRRC8A polyclonal antibodies against peptide sequence QRTKSRIEQGIVDRSE (from Rajan Sah's lab) 1:2,500 overnight, washed, and incubated with the secondary antibody of horseradish peroxidase-conjugated goat anti-rabbit IgG (1:5,000, Santa Cruz Biotech, catalog sc-2004) for 1.5 hours at room temperature. The antibody activities were detected by enhanced chemiluminescence detection system (Pierce Chemical) and exposure to X-ray film (Bioexpress Genemate). After this step, the membrane was stripped and reprobed with anti-GAPDH antibody (Cell Signaling Technology, clone D16H11).

IHC

Nodose neurons cultured on cover slips were fixed with $100 \%$ acetone at $-20^{\circ} \mathrm{C}$ permeabilized with $0.1 \%$ triton X-100 (Fisher Biotech) in PBS (Gibco), and blocked in 4\% goat serum. Three primary antibodies were applied and incubated in $4^{\circ} \mathrm{C}$ overnight. The dilution rates were: rabbit polyclonal antibodies against LRRC8A (from Rajan Sah's lab) 1:2,000 and mouse anti-NeuN antibody from Millipore 1:1,000 (MAB377), chicken anti-GFP from Aves (GFP-1020) 1:1,000. After 3 washes with PBS, cover slips were then incubated in secondary antibody in PBS with $4 \%$ goat serum at room temperature for 45 minutes. The dilution rate for secondary antibodies is 1:500 for goat anti-rabbit Alexa Fluor 568 (Invitrogen, catalog A21069), 1:500 for goat anti-chicken Alexa Fluor 488 (Invitrogen, catalog A11039), and 1:500 for goat anti-mouse Alexa Fluor 647 (Invitrogen, catalog A21235). The cover slips were washed with PBS 4 times and mounted with mounting medium (Vectashield HardSet antifade mounting medium with DAPI H-1500). Pictures were taken with Zeiss 1sm 710 inverted confocal microscopy in the Central Microscopy Facility of the University of Iowa. The color for Figure 4, B-D, was pseudo-colored.

\section{Chemicals/solutions}

The niflumic acid, tamoxifen, apocynin, amiloride, and DPI (all from Sigma-Aldrich) were dissolved in DMSO, and DCPIB was dissolved in ethanol to make a stock solution. The PEG-catalase and PEG-SOD (Sigma-Aldrich) were dissolved in bath solution directly, and $\mathrm{ZnCl}_{2}$ was dissolved in double-distilled water. DHE (Invitrogen) and BCECF-AM (Molecular Probes) were dissolved in DMSO. Stock solutions were diluted in bathing solutions to obtain the desired drug concentration. 


\section{Statistics}

Data are presented as mean \pm SE. Differences in means were tested using ANOVA when time and dose effects and more than 2 treatments were compared or using the paired or unpaired student $t$ test with Excel and Sigma Plot software. $P<0.05$ were accepted as significant.

\section{Study Approval}

The study was approved by the University of Iowa Institutional Animal Care and Use Committee (ACURF 4041019, L350 PBDB, 169 Newton Road, Iowa City, Iowa, USA) as required.

\section{Author Contributions}

RW designed and conducted the experiments; acquired, analyzed, and interpreted all data; and wrote the first draft of the manuscript. YL contributed to LRRC8A mRNA and protein sequence analysis, shRNA selection, and intracellular $\mathrm{pH}$ measurement and designed and conducted experiments on qPCR, Western blots, and intracellular ROS level. YZ contributed to generating LRRC8A KO HEK cells and patch clamped multiple LRRC8A KO clones to confirm that they are KO lines. SG designed and performed CRISP/Cas9 LRRC8A deletion in HEK cells, isolated clones, and validated the LRRC8A Ab against KO cell lines. CJB contributed to the original design and interpretation of the results and writing the manuscript. MWC contributed to the design planning and conduct of experiments, and editing the manuscript. RS contributed the design and supervision of experiments to provide the LRRC8A Ab, the shRNA1, the LRRC8A KO HEK cell line, and the novel floxed LRRC8A mice (unpublished). FMA developed the hypotheses and contributed to the design and conduct of the experiments; reviewed and interpreted the results; and wrote the manuscript.

\section{Acknowledgments}

We thank Arlinda LaRose and Angela M. Hester for assistance with word processing and manuscript preparation; Shawn Roach for help in editing the Figures; Carol A. Whiteis and Michael Cicha for assistance in isolating and culturing nodose neurons; Kristina W. Thiel for assistance with manuscript preparation; Fred S. Lamb for consultation; Michael J. Welsh for the use of laboratory facilities and for consultation; Huiyu Gong for helping with the immunostaining; and Thomas O. Moninger for help with $\mathrm{pH}$ imaging. We also thank the University of Iowa DNA Facility, Central Microscopy Research Facility, and Office of Animal Resources for support.

The work was supported by Program Project grant HL014388-42 from the NIH (FMA, MWC, and CJB), NIDDK, 1RO1DK106009 (RS), Department of Veterans Affairs VA Merit Award 1 BX001414 (MWC), and VA Merit Award BX000776 (CJB), as well as the NHLBI T32 Iowa Cardiovascular Interdisciplinary Research Fellowship HL007121 (RW), the American Heart Association Fellow-to-Faculty award (RS), American Cancer Society Pilot Grant (RS), and Roy J. Carver Trust (RS).

Address correspondence to: François M. Abboud or Runping Wang, Abboud Cardiovascular Research Center, 616 MRC (F.M. Abboud) or 602 MRC (R. Wang), 501 Newton Road, University of Iowa, Iowa City, Iowa 52242, USA. Phone: 319.335.7708; E-mail: francois-abboud@uiowa.edu (F.M. Abboud). Phone: 319.335.7684; E-mail: runping-wang@uiowa.edu (R. Wang).

1. Browning KN, Mendelowitz D. Musings on the wanderer: what's new in our understanding of vago-vagal reflexes?: II. Integration of afferent signaling from the viscera by the nodose ganglia. Am J Physiol Gastrointest Liver Physiol. 2003;284(1):G8-14

2. Daly DM, Park SJ, Valinsky WC, Beyak MJ. Impaired intestinal afferent nerve satiety signalling and vagal afferent excitability in diet induced obesity in the mouse. J Physiol (Lond). 2011;589(Pt 11):2857-2870.

3. Oh EJ, Weinreich D. Bradykinin decreases $\mathrm{K}(+)$ and increases $\mathrm{Cl}(-)$ conductances in vagal afferent neurones of the guinea pigs. J Physiol (Lond). 2004;558(Pt 2):513-526.

4. Snitsarev V, Whiteis CA, Chapleau MW, Abboud FM. Neuronal prostacyclin is an autocrine regulator of arterial baroreceptor activity. Hypertension. 2005;46(3):540-546.

5. Snitsarev V, Whiteis CA, Chapleau MW, Abboud FM. Mechano- and chemosensitivity of rat nodose neurones--selective excitatory effects of prostacyclin. J Physiol (Lond). 2007;582(Pt 1):177-194.

6. Yu S, Ouyang A. TRPA1 in bradykinin-induced mechanical hypersensitivity of vagal C fibers in guinea pig esophagus. $A m J$ Physiol Gastrointest Liver Physiol. 2009;296(2):G255-G265.

7. Schultz HD. Cardiac vagal chemosensory afferents. Function in pathophysiological states. Ann N Y Acad Sci. 2001;940:59-73. 
8. Longhurst JC, Tjen-A-Looi SC, Fu LW. Cardiac sympathetic afferent activation provoked by myocardial ischemia and reperfusion. Mechanisms and reflexes. Ann N Y Acad Sci. 2001;940:74-95.

9. Huang HS, Pan HL, Stahl GL, Longhurst JC. Ischemia- and reperfusion-sensitive cardiac sympathetic afferents: influence of H2O2 and hydroxyl radicals. Am J Physiol. 1995;269(3 Pt 2):H888-H901.

10. Huang HS, Stahl GL, Longhurst JC. Cardiac-cardiovascular reflexes induced by hydrogen peroxide in cats. Am JPhysiol. 1995;268(5 Pt 2):H2114-H2124.

11. Sugiura T, Dang K, Lamb K, Bielefeldt K, Gebhart GF. Acid-sensing properties in rat gastric sensory neurons from normal and ulcerated stomach. J Neurosci. 2005;25(10):2617-2627.

12. Gu Q, Lee LY. Characterization of acid signaling in rat vagal pulmonary sensory neurons. Am J Physiol Lung Cell Mol Physiol. 2006;291(1):L58-L65.

13. Benson CJ, Eckert SP, McCleskey EW. Acid-evoked currents in cardiac sensory neurons: A possible mediator of myocardial ischemic sensation. Circ Res. 1999;84(8):921-928.

14. Pan HL, Longhurst JC, Eisenach JC, Chen SR. Role of protons in activation of cardiac sympathetic C-fibre afferents during ischaemia in cats. $J$ Physiol (Lond). 1999;518 (Pt 3):857-866.

15. Lu Y, et al. The ion channel ASIC2 is required for baroreceptor and autonomic control of the circulation. Neuron. 2009;64(6):885-897.

16. Stahl GL, Longhurst JC. Ischemically sensitive visceral afferents: importance of $\mathrm{H}+$ derived from lactic acid and hypercapnia Am J Physiol. 1992;262(3 Pt 2):H748-H753

17. Gebhart GF, ed. Visceral Pain: The Bristol-Myers Squibb Symposium on Pain Research. Progress in pain research and management. Vol. 5. Seattle, Washington, USA: International Association for the Study of Pain Press; 1995.

18. Qiu Z, et al. SWELL1, a plasma membrane protein, is an essential component of volume-regulated anion channel. Cell. 2014;157(2):447-458.

19. Voss FK, et al. Identification of LRRC8 heteromers as an essential component of the volume-regulated anion channel VRAC. Science. 2014;344(6184):634-638.

20. Syeda R, et al. LRRC8 Proteins Form Volume-Regulated Anion Channels that Sense Ionic Strength. Cell. 2016;164(3):499-511.

21. Gautam M, Benson CJ. Acid-sensing ion channels (ASICs) in mouse skeletal muscle afferents are heteromers composed of ASIC1a, ASIC2, and ASIC3 subunits. FASEB J. 2013;27(2):793-802.

22. Ru F, Banovcin P, Kollarik M. Acid sensitivity of the spinal dorsal root ganglia C-fiber nociceptors innervating the guinea pig esophagus. Neurogastroenterol Motil. 2015;27(6):865-874.

23. Andersen OS, Koeppe RE, Roux B. Gramicidin channels. IEEE Trans Nanobioscience. 2005;4(1):10-20.

24. Kaneko H, Putzier I, Frings S, Kaupp UB, Gensch T. Chloride accumulation in mammalian olfactory sensory neurons. J Neurosci. 2004;24(36):7931-7938.

25. Gilbert D, Franjic-Würtz C, Funk K, Gensch T, Frings S, Möhrlen F. Differential maturation of chloride homeostasis in primary afferent neurons of the somatosensory system. Int J Dev Neurosci. 2007;25(7):479-489.

26. Ren Z, Baumgarten CM. Antagonistic regulation of swelling-activated Cl-current in rabbit ventricle by Src and EGFR protein tyrosine kinases. Am J Physiol Heart Circ Physiol. 2005;288(6):H2628-H2636.

27. Valverde MA, Mintenig GM, Sepúlveda FV. Differential effects of tamoxifen and I- on three distinguishable chloride currents activated in T84 intestinal cells. Pflugers Arch. 1993;425(5-6):552-554.

28. Prosser BL, Ward CW, Lederer WJ. X-ROS signaling: rapid mechano-chemo transduction in heart. Science. 2011;333(6048):1440-1445.

29. Ren Z, Raucci FJ, Browe DM, Baumgarten CM. Regulation of swelling-activated Cl(-) current by angiotensin II signalling and NADPH oxidase in rabbit ventricle. Cardiovasc Res. 2008;77(1):73-80.

30. Wu LJ, et al. The voltage-gated proton channel Hv1 enhances brain damage from ischemic stroke. Nat Neurosci. 2012;15(4):565-573.

31. DeCoursey TE, Morgan D, Cherny VV. The voltage dependence of NADPH oxidase reveals why phagocytes need proton channels. Nature. 2003;422(6931):531-534.

32. Mellergård P, Ouyang YB, Siesjö BK. The regulation of intracellular $\mathrm{pH}$ is strongly dependent on extracellular $\mathrm{pH}$ in cultured rat astrocytes and neurons. Acta Neurochir Suppl (Wien). 1994;60:34-37.

33. Murphy JK, Forman HJ. Effects of sodium and proton pump activity on respiratory burst and $\mathrm{pH}$ regulation of rat alveolar macrophages. Am J Physiol. 1993;264(5 Pt 1):L523-L532.

34. Liu Y, et al. Activation of microglia depends on $\mathrm{Na}+/ \mathrm{H}+$ exchange-mediated $\mathrm{H}+$ homeostasis. $J$ Neurosci. 2010;30(45):15210-15220

35. Shimoda LA, Fallon M, Pisarcik S, Wang J, Semenza GL. HIF-1 regulates hypoxic induction of NHE1 expression and alkalinization of intracellular pH in pulmonary arterial myocytes. Am J Physiol Lung Cell Mol Physiol. 2006;291(5):L941-L949.

36. Lishko PV, Botchkina IL, Fedorenko A, Kirichok Y. Acid extrusion from human spermatozoa is mediated by flagellar voltage-gated proton channel. Cell. 2010;140(3):327-337.

37. Kilic A, et al. Enhanced activity of the myocardial Na+/H+ exchanger NHE-1 contributes to cardiac remodeling in atrial natriuretic peptide receptor-deficient mice. Circulation. 2005;112(15):2307-2317.

38. Gekle M, Golenhofen N, Oberleithner H, Silbernagl S. Rapid activation of $\mathrm{Na}+\mathrm{H}+$ exchange by aldosterone in renal epithelial cells requires $\mathrm{Ca} 2+$ and stimulation of a plasma membrane proton conductance. Proc Natl Acad Sci USA. 1996;93(19):10500-10504.

39. Olszewski U, Hamilton G. Neurotensin signaling induces intracellular alkalinization and interleukin-8 expression in human pancreatic cancer cells. Mol Oncol. 2009;3(3):204-213.

40. Nordström T, et al. Regulation of cytoplasmic $\mathrm{pH}$ in osteoclasts. Contribution of proton pumps and a proton-selective conductance. J Biol Chem. 1995;270(5):2203-2212.

41. Smith SM, et al. Voltage-gated proton channel in a dinoflagellate. Proc Natl Acad Sci USA. 2011;108(44):18162-18167.

42. Diaz RJ, Armstrong SC, Batthish M, Backx PH, Ganote CE, Wilson GJ. Enhanced cell volume regulation: a key protective mechanism of ischemic preconditioning in rabbit ventricular myocytes. J Mol Cell Cardiol. 2003;35(1):45-58.

43. Diaz RJ, Losito VA, Mao GD, Ford MK, Backx PH, Wilson GJ. Chloride channel inhibition blocks the protection of ischemic 
preconditioning and hypo-osmotic stress in rabbit ventricular myocardium. Circ Res. 1999;84(7):763-775.

44. Jentsch TJ. VRACs and other ion channels and transporters in the regulation of cell volume and beyond. Nat Rev Mol Cell Biol. 2016;17(5):293-307.

45. Pedersen SF, Okada Y, Nilius B. Biophysics and Physiology of the Volume-Regulated Anion Channel (VRAC)/Volume-Sensitive Outwardly Rectifying Anion Channel (VSOR). Pflugers Arch. 2016;468(3):371-383.

46. Sirianant L, et al. Non-essential contribution of LRRC8A to volume regulation. Pflugers Arch. 2016;468(5):805-816.

47. Browe DM, Baumgarten CM. EGFR kinase regulates volume-sensitive chloride current elicited by integrin stretch via PI-3K and NADPH oxidase in ventricular myocytes. J Gen Physiol. 2006;127(3):237-251.

48. Ren Z, Raucci FJ, Browe DM, Baumgarten CM. Regulation of swelling-activated Cl(-) current by angiotensin II signalling and NADPH oxidase in rabbit ventricle. Cardiovasc Res. 2008;77(1):73-80.

49. Mederos y Schnitzler M, Storch U, Gudermann T. AT1 receptors as mechanosensors. Curr Opin Pharmacol. 2011;11(2):112-116.

50. Mederos y Schnitzler M, et al. Gq-coupled receptors as mechanosensors mediating myogenic vasoconstriction. EMBO J. 2008;27(23):3092-3103.

51. Price TJ, Hargreaves KM, Cervero F. Protein expression and mRNA cellular distribution of the NKCC1 cotransporter in the dorsal root and trigeminal ganglia of the rat. Brain Res. 2006;1112(1):146-158.

52. Glykys J, et al. Local impermeant anions establish the neuronal chloride concentration. Science. 2014;343(6171):670-675.

53. Kamsler A, Segal M. Paradoxical actions of hydrogen peroxide on long-term potentiation in transgenic superoxide dismutase-1 mice. J Neurosci. 2003;23(32):10359-10367

54. Lee KY, Chung K, Chung JM. Involvement of reactive oxygen species in long-term potentiation in the spinal cord dorsal horn. J Neurophysiol. 2010;103(1):382-391.

55. Thiels E, et al. Impairment of long-term potentiation and associative memory in mice that overexpress extracellular superoxide dismutase. J Neurosci. 2000;20(20):7631-7639.

56. Otani H. Oxidative stress as pathogenesis of cardiovascular risk associated with metabolic syndrome. Antioxid Redox Signal. 2011;15(7):1911-1926.

57. Mastitskaya S, et al. Cardioprotection evoked by remote ischaemic preconditioning is critically dependent on the activity of vagal pre-ganglionic neurones. Cardiovasc Res. 2012;95(4):487-494.

58. Donato M, et al. Role of the parasympathetic nervous system in cardioprotection by remote hindlimb ischaemic preconditioning. Exp Physiol. 2013;98(2):425-434.

59. Abboud FM, Mark AL, Thames MD. Modulation of the somatic reflex by carotid baroreceptors and by cardiopulmonary afferents in animals and in humans. Circ Res. 1981;48(6 Pt 2):I131-I137.

60. Liu Z, et al. Glutamate release predicts ongoing myocardial ischemia of rat hearts. Scand J Clin Lab Invest. 2010;70(3):217-224

61. Gaitán-Peñas H, et al. Investigation of LRRC8-Mediated Volume-Regulated Anion Currents in Xenopus Oocytes. Biophys J. 2016;111(7):1429-1443.

62. Tan ZY, Lu Y, Whiteis CA, Benson CJ, Chapleau MW, Abboud FM. Acid-sensing ion channels contribute to transduction of extracellular acidosis in rat carotid body glomus cells. Circ Res. 2007;101(10):1009-1019.

63. Bidani A, Brown SE, Heming TA, Gurich R, Dubose TD. Cytoplasmic pH in pulmonary macrophages: recovery from acid load is $\mathrm{Na}+$ independent and NEM sensitive. Am J Physiol. 1989;257(1 Pt 1):C65-C76.

64. Murillo Pulgarín JA, Alañón Molina A, Fernández López P. Direct determination of amiloride in urine using isopotential fluorimetry. Analyst. 1997;122(3):247-252. 